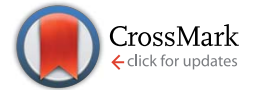

Cite this: Nat. Prod. Rep., 2015, 32, 1236

\section{Biological activity of natural sesquiterpenoids containing a gem-dimethylcyclopropane unit $\uparrow$}

\author{
María Jesús Durán-Peña, ${ }^{a}$ José Manuel Botubol Ares, ${ }^{a}$ James R. Hanson, ${ }^{b}$
}

Isidro G. Collado*a and Rosario Hernández-Galán*a

\section{Covering: 1963 up to the end of 2014}

The biological activities of aristolane, aromadendrane, ent-1,10-secoaromadendrane, 2,3secoaromadendrane, ent-5,10-cycloaromadendrane, bicyclogermacrene, lepidozane, and maaliane terpenoids which contain the gem-dimethylcyclopropyl unit are described. Particular attention is given to their anti-viral, anti-microbial and cytotoxic activities. In the main text there are 119 references covering the literature from 1963-2014. The ESI contains tables listing 332 of these terpenoids, their occurrence and biological activity together with the related references.
Received 17th February 2015

DOI: $10.1039 / c 5 n p 00024 f$

www.rsc.org/npr
2.9 The biological role of the gem-dimethylcyclopropane unit in sesquiterpenes

Sesquiterpenoids

Aristolanes (structures 1-50)

2.1.1 Antimicrobial activity

2.1.2 Cytotoxic activity

2.1.3 Other activities

2.2 Aromadendranes (structures 51-190)

2.2.1 Antifeedant, antifouling and insect repellent activity

2.2.2 Antimicrobial activity

2.2.3 Antiviral activity

2.2.4 Cytotoxic activity

2.2.5 Other activities

2.3 ent-1,10-Secoaromadendranes (structures 191-195)

$2.4 \quad 2,3-$ Secoaromadendranes (structures 196-226)

2.5 ent-5,10-Cycloaromadendranes (structures 227-231)

2.6 Lepidozanes and bicyclogermacrenes (structures 232283)

2.6.1 Cytotoxic activity

2.6.2 Other activities

2.7 Maalianes (structures 284-305)

2.8 Miscellaneous sesquiterpenoids (structures 306-332)

2.8.1 Antimicrobial activity

2.8.2 Cytotoxic activity

2.8.3 Other activities

${ }^{a}$ Department of Organic Chemistry, Faculty of Science, University of Cádiz, Polígono Río San Pedro s/n, 11510, Puerto Real, Cádiz, Spain. E-mail: isidro.gonzalez@uca. es; rosario.hernandez@uca.es

${ }^{b}$ Department of Chemistry, University of Sussex, Brighton, Sussex, BN1 9QJ, UK $\dagger$ Electronic supplementary information (ESI) available: Tables listing the compounds, the species from which they were isolated, their biological activity and the bibliographical reference. See DOI: 10.1039/c5np00024f

\section{Conclusions}

Abbreviations

Acknowledgements

References

\section{Introduction}

Although sesquiterpenes ${ }^{1-6}$ and diterpenes ${ }^{7-11}$ have been the subject of numerous reviews, sesquiterpenes containing a gemdimethylcyclopropyl subunit need a comprehensive review because of the wide range of their potentially valuable biological activities and broad structural diversity.

These three-membered carbocycles are found in various compounds, particularly terpenoids, which have been isolated from a large number of organisms including plants, liverworts, fungi and marine organisms such as soft corals, sponges or sea slugs.

In this article we provide a comprehensive report of sesquiterpenoid natural products containing a gem-dimethylcyclopropyl subunit, which may affect their biological activities. This review, with more than 119 references, covers the literature in this field from 1963 to 2014. Tables containing compounds, the species from which they were isolated, their biological activities and the references where they were described, are included in the ESI $\uparrow$ of this paper.

\section{Sesquiterpenoids}

There are many natural products that contain a gem-dimethylcyclopropane ring as part of a sesquiterpene skeleton 


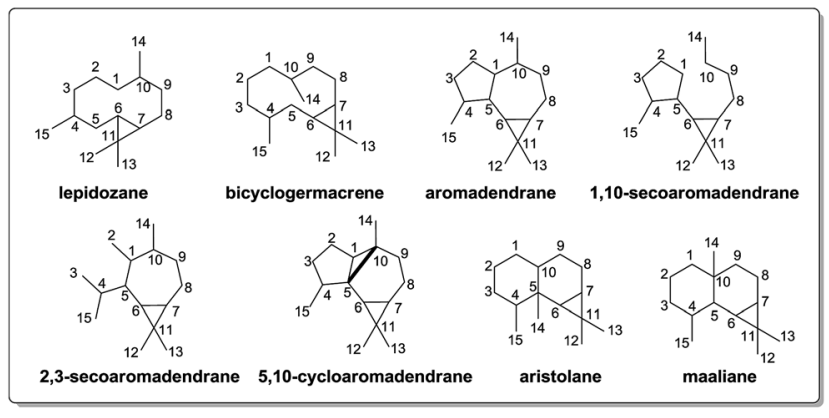

Fig. 1 Sesquiterpene skeleta containing a gemdimethylcyclopropane.

including bicyclogermacrenes, lepidozanes, aromadendranes, ent-1,10-secoaromadendranes, 2,3-secoaromadendranes, ent5,10-cycloaromadendranes, aristolanes and maalianes (Fig. 1).

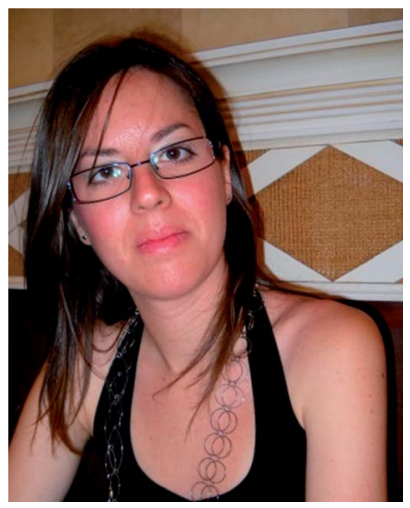

María Jesús Durán-Peña was born in 1984 in Cadiz, Spain. She studied chemistry at the University of Cádiz. She carried out her PhD at Cádiz University with Professor Dr R. H. Galán and Professor Dr I. G. Collado. Her work focused on the isolation of secondary metabolites from euphorbia species and the development of new methodologies of cyclopropanation. She then worked as a postdoctoral fellow with Professor Timothy D. H. Bugg on biotechnological enhancement of lignocellulose degradation at Warwick University.
These groups are structurally related sesquiterpenes containing a fused dimethylcyclopropane ring and it has been proposed that they possibly have a common biosynthetic origin (Fig. 2). ${ }^{12,13}$ These sesquiterpenes are derived from $(2 E, 6 E)$-farnesyl pyrophosphate which is converted into bicyclogermacrene by the enzyme bicyclogermacrene synthase after 1,3-deprotonation of the corresponding carbocation. The latter is believed to be the biosynthetic precursor of aromadendranes, aristolanes and maalianes through regiospecific cyclisations followed by either suitable hydride or methyl shifts. An anti-Markovnikovoriented cyclisation of the most stable conformer of bicyclogermacrene would lead to aromadendranes whereas a Markovnikov-oriented cyclisation yields the maalianes. Finally, 1,2migration of a methyl group from the maaliane cation would yield the aristolanes. ${ }^{\mathbf{1 4}}$

On the other hand, 2,3-secoaromadendranes and 5,10cycloaromadendranes are probably derived from the appropriate cyclisation or bond cleavages of the corresponding aromadendranes. Finally, lepidozanes could be derived by a

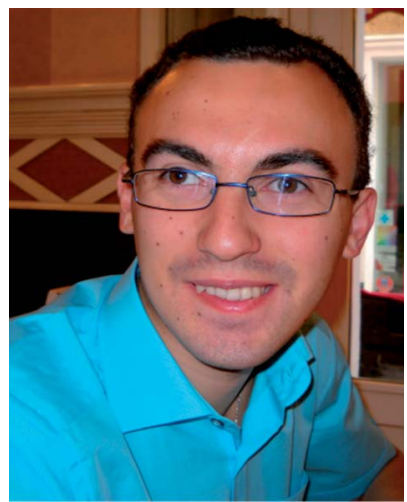

José Manuel Botubol was born in 1984 in Cadiz, Spain. He studied chemistry at the University of Cádiz. He carried out his PhD at Cádiz University with Professor Dr I. G. Collado and $\operatorname{Dr}$ A. J. Macias-Sánchez where he was working on the total synthesis of polyketide natural products. His further research interests are the synthesis of biologically active molecules.

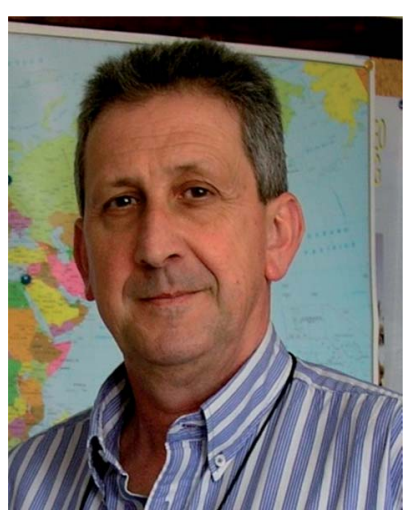

Isidro G. Collado is a Professor of Organic Chemistry at the University of Cadiz, Spain. He received a BSc in Chemistry from the University of Seville in 1978. After working for one year at the Faculty of Sciences of Cadiz University on the synthesis of pyrrol derivatives, he completed his PhD on natural product chemistry under the tutelage of Prof. Dr G. M. Massanet. He then worked as a postdoctoral fellow with Professors B. M. Fraga and J. R. Hanson on gibberellin chemistry at the Consejo Superior de Investigaciones Cientificas (Tenerife) and Sussex University, respectively. His current research interests include the genomic bases of natural product biosynthesis, synthesis of bioactive molecules and design of selective fungicides.

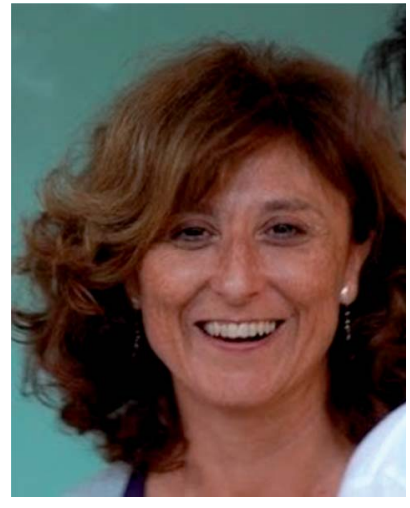

R. Hernández-Galán is a Professor of Organic Chemistry at the University of Cádiz, Spain. She obtained her PhD Degree from the University of Cádiz in 1991 for her work on the synthesis of 3-(1,1-dimethylallyl)coumarins under the tutelage of Professor F. R. Luis. She completed her PhD studies at Dyson Perrins Laboratory (Oxford) with Professor Laurence M. Harwood. Her current research interest includes the biosynthesis of natural products, synthesis of bioactive compounds and the design and synthesis of agonists of PKCs. 


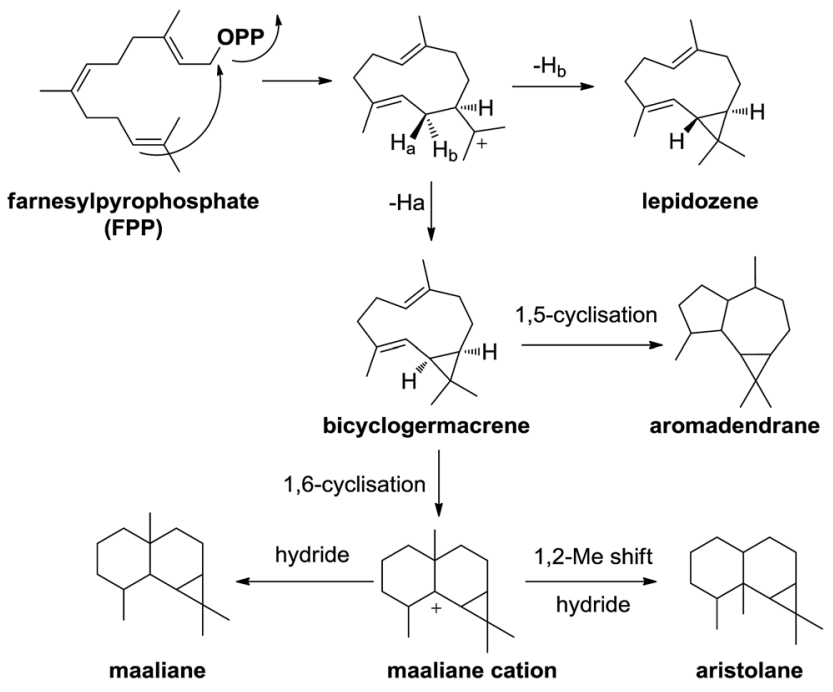

Fig. 2 Proposed common biosynthetic pathway for sesquiterpenes containing a gem-dimethylcyclopropane unit. ${ }^{13}$

suitable proton elimination to produce a trans cyclopropane ring. ${ }^{14}$

These sesquiterpenes have been isolated from diverse sources and possess a wide variety of biological activities such as cytotoxic, antimicrobial or antifeedant allelopathic activity. The biological activity will be discussed in the context of their different carbon skeleta.

\subsection{Aristolanes (structures 1-50)}

Aristolane sesquiterpenes are rare in nature although they have been isolated both from terrestrial plants and marine organisms ${ }^{15}$ as well as from the fungus Russula lepida. They have been tested and reveal different biological activities.

2.1.1 Antimicrobial activity. Aurisins A, G, and K (1-3) are dimeric aristolanes that exhibited antimalarial activity against Plasmodium falciparum. The aurisins A (1) and K (3) also showed antimycobacterial activity against Mycobacterium tuberculosis. However, nambinone $\mathrm{C}$ (4) was not active in any of these assays. ${ }^{16}$ Axinysones A and B (6 and 7), and anthracophyllone (8)

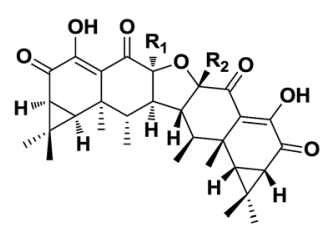

$1 \mathrm{R}_{1}=\mathrm{R}_{2}=\mathrm{OH}$ (aurisin $\mathrm{A}$ ) $2 \mathrm{R}_{1}=\mathrm{OH}, \mathrm{R}_{2}=\mathrm{OMe}$ (aurisin $\mathrm{G}$ ) $3 \mathrm{R}_{1}=\mathrm{OH}, \mathrm{R}_{2}=\mathrm{H}$ (aurisin K)

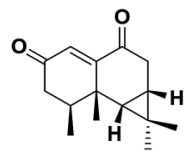

8 (anthracophyllone)

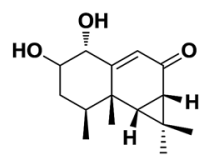

$4 \beta-\mathrm{OH}$ (nambinone $\mathrm{C}$ ) $5 \alpha-\mathrm{OH}$ (rulepidadiol $\mathrm{B}$ )

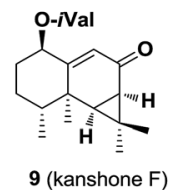

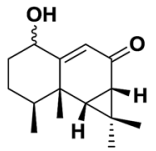

$6 \alpha-\mathrm{OH}$ (axinysone A) $7 \beta-\mathrm{OH}$ (axinysone $\mathrm{B}$ ) were evaluated for antimalarial activity and activity against Bacillus cereus but again they were inactive. ${ }^{17}$ Kanshone F (9) was examined against $P$. falciparum but it did not show any promising activity. ${ }^{18}$ There is a clear difference between the hydrophilic and hydrophobic faces of the dimers.

2.1.2 Cytotoxic activity. Aurisins A, G, and K (1-3) were evaluated for cytotoxic activity against KB, MCF-7, NCI-H187, and Vero cells. These three compounds displayed biological activity against KB and NCI-H187. Moreover aurisins A (1) and K (3) showed cytotoxicity against Vero cells and the cholangiocarcinoma cell lines. ${ }^{16,17}$ However, nambinone C (4) was evaluated against BC-1, KB, cholangiocarcinoma, and NCI-H187 cell lines showing cytotoxicity against the latter ${ }^{\mathbf{1 6}}$ whereas its epimer rulepidadiol B (5) was inactive when it was tested for in vitro inhibitory activity on the proliferation of A-549, CAKI 1 , and WISH cell lines in a $48 \mathrm{~h}$ MTT essay. ${ }^{19}$ Furthermore, the axinysones A and B ( 6 and 7) were tested against a NCl-H187 cell line but only axinysone A (6) exhibited specific cytotoxicity against this cell line. ${ }^{17}$ These results might indicate an important effect of the stereochemistry of the hydroxyl groups at C-1 and $\mathrm{C}-2$ in the cytotoxic activity. It would appear that the presence of an $\alpha$-hydroxyl group at C- 1 is crucial for cytotoxicity as in the case of compounds 4 and $\mathbf{6}$, since compound 8 with a $\beta$ hydroxyl group at the $\mathrm{C}-1$ position was inactive. Furthermore, the presence of a vicinal hydroxyl group at the C-2 position should have a trans disposition with respect the $\alpha$-hydroxyl group at $\mathrm{C}-\mathbf{1}$ as is the case for nambinone $\mathrm{C}(\mathbf{4})$. The isomer rulepidadiol (5) with the $\alpha$-hydroxyl group at $\mathrm{C}-2$ was inactive.

The enedione anthracophyllone (8) exhibited cytotoxicity against KB, MCF-7, NCI-H187 and Vero cells. However, axinysones $\mathrm{A}-\mathrm{D}(\mathbf{6}, 7,10$ and 11), axinynitrile $\mathrm{A}(\mathbf{1 2})$ and $(+)$-aristolone (13) were inactive against the human tumor cell lines MDA-MB231, A-549, and HT-29. ${ }^{20}$ Axinysone E (14) was mildly active against the human tumor cell lines A-549 and HT-29 ${ }^{20}$ and debilon (15) showed cytotoxic activity against P-388 cells. ${ }^{21}$
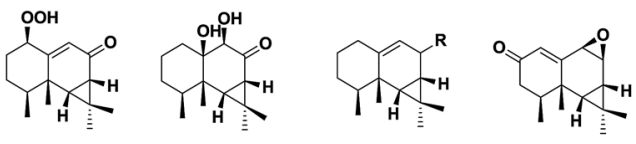

$12 \mathrm{R}=\alpha$-CN (axinynitrile A) 14 (axinysone $\mathrm{E}$ ) $13 \mathrm{R}=\mathrm{=}=\mathrm{O}((+)$-aristolone $)$

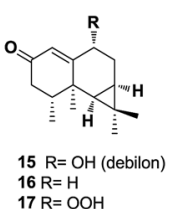

$16 \mathrm{R}=\mathrm{H}$
$17 \mathrm{R}=\mathrm{OOH}$

2.1.3 Other activities. Nardoaristolone A (18) was evaluated for its protective effects against $\mathrm{H}_{2} \mathrm{O}_{2}$-induced myocardial injury. This effect was dose-dependent. ${ }^{22}$ Kanshone C (19) is a highly oxidized aristolane-type sesquiterpenoid ${ }^{23}$ that showed a remarkable protective activity against $\mathrm{D}$-galactosamine-induced liver damage in rat hepatocytes. ${ }^{24}$ Finally, (+)-9-aristolene (20) inhibited the metamorphosis of the barnacle Balanus amphitrite. ${ }^{25}$

\subsection{Aromadendranes (structures 51-190)}

Aromadendranes are the most abundant group of compounds containing a gem-dimethylcyclopropane ring. They contain gemdimethylcyclopropane fused to a hydroazulene skeleton (bicycle [5.3.0]decapentane). Aromadendranes have been isolated from the oil or resin of different tree species whereas ent- 

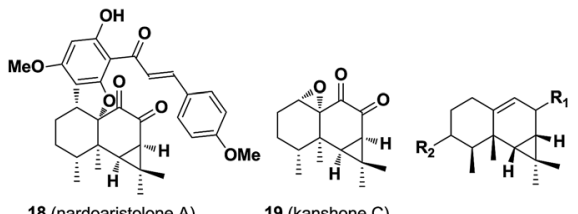

$20 \mathrm{R}_{1}=\mathrm{R}_{2}=\mathrm{H}((+)-9$-aristolene) $21 \mathrm{R}_{1}=\beta-\mathrm{OMe}, \mathrm{R}_{2}=\mathrm{H}$

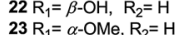
$23 \mathrm{R}_{1}=\alpha-\mathrm{OMe}, \mathrm{R}_{2}=H$
$24 \mathrm{R}_{1}=\mathrm{H}, \mathrm{R}_{2}==\mathrm{O}$ $25 \mathrm{R}_{1}=\mathrm{H}, \mathrm{R}_{2}=\beta-\mathrm{OH}$

18 (nardoaristolone A) 19 (kanshone $C$ )
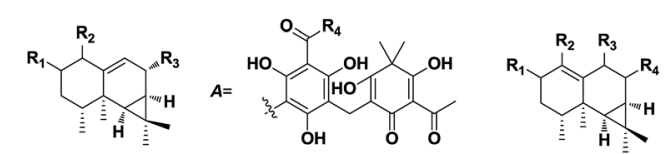
$26 \mathrm{R}_{1}=\mathrm{H}, \mathrm{R}_{2}=\alpha-\mathrm{OH}, \mathrm{R}_{3}==\mathrm{O}$
$27 \mathrm{R}_{1}=\mathrm{R}_{2}=\mathrm{R}_{3}=\mathrm{H}$

$28 R_{1}=R_{2}=H, R_{3}==0$

$29 R_{1}=R_{2}=H, R_{3}=A, R_{4}=M e$ (atrata-phloroglucinol A) $30 \mathrm{R}_{1}=\mathrm{R}_{2}=\mathrm{H}, \mathrm{R}_{3}=A, \mathrm{R}_{4}=$ propyl (atrata-phloroglucinol $\mathrm{B}$ ) $31 \mathrm{R}_{1}=\alpha-\mathrm{OH}, \mathrm{R}_{2}=\mathrm{H}, \mathrm{R}_{3}==\mathrm{O}$ (rulepidol) $32 \mathrm{R}_{1}=\mathrm{R}_{3}=\mathrm{H}, \mathrm{R}_{2}==\mathrm{O}$ $33 \mathrm{R}_{1}=\mathrm{H}, \mathrm{R}_{2}=\beta$-isopentyloxy, $\mathrm{R}_{3}==0$ $34 \mathrm{R}_{1}=\mathrm{R}_{3}=\mathrm{H}, \mathrm{R}_{2}=\alpha-\mathrm{OH}$

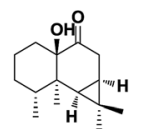

42

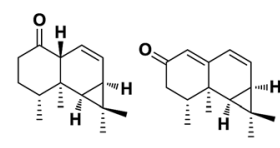

43
$35 R_{1}=R_{3}=\beta-O H, R_{2}=R_{4}=H$ (kanshone $G$ ) $36 R_{1}=R_{2}=R_{4}=H, R_{3}==O$ (gansogone) $37 \mathrm{R}_{1}==\mathrm{O}, \mathrm{R}_{2}=\mathrm{R}_{3}=\mathrm{R}_{4}=\beta$ - $\mathrm{OH}$ (rulepidadiol) $38 R_{1}=R_{3}=R_{4}==0, R_{2}=N_{2}$ (lepidamine) $39 \mathrm{R}_{1}==\mathrm{O}, \mathrm{R}_{2}=\mathrm{R}_{4}=\mathrm{H}, \mathrm{R}_{3}=\alpha-\mathrm{OOH}$ $40 R_{1}=R_{2}=R_{3}=R_{4}=H$ ( $\beta$-gurjunene)

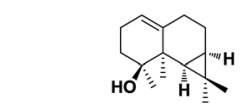

41 (calarenol)

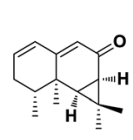

45

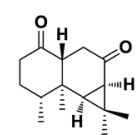

46

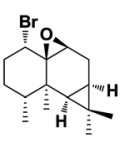

47
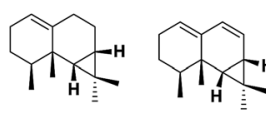

49

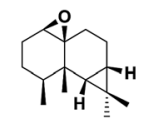

50 aromadendranes, which have the mirror image carbon skeleta, have been found in liverworts such as Heteroscyphus planus, Mylia nuda or Calypogeia azurea. This large group of compounds are discussed in terms of their biological activities.

2.2.1 Antifeedant, antifouling and insect repellent activity. Spathulenol (51) showed repellent activity against the leaf cutter ant $^{26}$ and compound $\mathbf{5 2}$ was toxic to the Southeast Asian termites (Neotermes spp.) and played an important role in defence against these insects. ${ }^{27}$ Finally, the glycosides pittosporanoside A1 and A2 (53 and 54) are active repellent substances against the blue mussel (Mytilus edulis) whereas compounds 55 and 56 inhibit the metamorphosis of the barnacle B. amphitrite. ${ }^{25}$

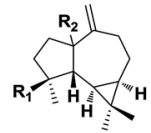

$51 \mathrm{R}_{1}=\mathrm{OH}, \mathrm{R}_{2}=\alpha-\mathrm{H}$ (spathulenol) $52 \mathrm{R}_{1}=\mathrm{H}, \mathrm{R}_{2}=\beta-\mathrm{H}$

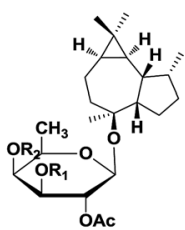

$53 \mathrm{R}_{1}=$ Ang, $\mathrm{R}_{2}=\mathrm{H}$ (pittosporanosides A1) $\mathbf{5 4} \mathrm{R}_{1}=\mathrm{H}, \mathrm{R}_{2}=$ Ang
(pittosporanosides $A 2$ )

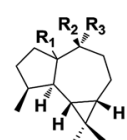

$55 \mathrm{R}_{1}=\alpha-\mathrm{H}, \mathrm{R}_{2}=\mathrm{Me}, \mathrm{R}_{3}=\mathrm{NCS}$ $56 \mathrm{R}_{1}=\beta-\mathrm{H}, \mathrm{R}_{2}=\mathrm{NCS}, \mathrm{R}_{3}=\mathrm{Me}$ (epipolasin-B)
2.2.2 Antimicrobial activity. Spathulenol (51) showed activity against Staphylococcus aureus and Proteus mirabilis ${ }^{28}$ whereas allo-aromadendranes $\mathbf{5 7}$ and $\mathbf{5 8}$ displayed antimycobacterial activity against $M$. tuberculosis. $^{29}$ Moreover, compound $\mathbf{5 7}$ was identified as the sesquiterpenoid responsible for the antibacterial activity of the leaves of Duguetia glabriuscula. ${ }^{30}$ Macrocarpals A-C (59-61) are terpenes which were isolated from Eucalyptus macrocarpa with structures that are characterized by an isopentyl phloroglucinol dialdehyde fused to an aromadendrane skeleton. They showed activity against Gram-positive bacteria such as Bacillus subtilis PCI219 and $S$. aureus FDA209P. ${ }^{31,32}$ Additionally macrocarpals A-C (5961) exhibited antibacterial effects against not only Gram-positive bacteria, but also Gram-negative periodontopathic bacteria with more than $60 \%$ inhibition. ${ }^{33-35}$ Sesquiterpenes 62 and 63 are two antimicrobial components of Acanthella pulcherrima ${ }^{36}$ whereas halichonadin F (64) showed antimicrobial activity against Micrococcus luteus, Trichophyton mentagrophytes and Cryptococcus neoformans. ${ }^{37}$ Compound 65 inhibits the growth of B. subtilis and M. luteus but it had no effects on E. coli. ${ }^{38}$ Both aromadendrane and ent-aromadendrane can inhibit the growth of M. luteus as is the case for compounds 64 and 65 .
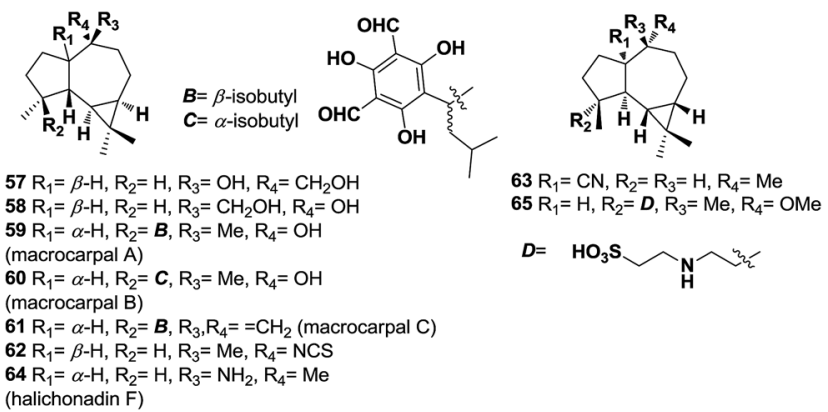

Ledol (66), viridiflorol (67) and compounds 68 and 69 are also aromadendranes with antifungal activity. Ledol (66) showed activity against Coriolus ronatus ${ }^{39}$ and Cladosporium cucumerinum $^{40}$ whereas viridiflorol (67) showed weak activity against C. cucumerinum $^{40}$ and Pyricularia oryzae. ${ }^{41}$ Alloaromadendrane 68, isolated from the aerial part of Ambrosia peruviana, was a very effective inhibitor of the growth of Cladosporium herbarum ${ }^{42}$ and compound 69 exhibited anti-P. oryzae activity. ${ }^{43}$

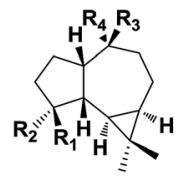

$$
\begin{aligned}
& 66 \mathrm{R}_{1}=\mathrm{H}, \mathrm{R}_{2}=\mathrm{R}_{3}=\mathrm{Me}, \mathrm{R}_{4}=\mathrm{OH} \text { (ledol) } \\
& 67 \mathrm{R}_{1}=\mathrm{H}, \mathrm{R}_{2}=\mathrm{R}_{4}=M e, \mathrm{R}_{3}=\mathrm{OH} \text { (viridiflorol) } \\
& 68 \mathrm{R}_{1}=\mathrm{R}_{4}=\mathrm{Me}, \mathrm{R}_{2}=\mathrm{R}_{3}=\mathrm{OH}
\end{aligned}
$$

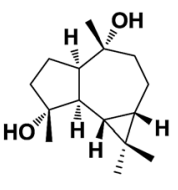

69
Millecrone B (70) was inactive against Candida albicans but inhibited the growth of both $S$. aureus and B. subtilis. ${ }^{44}$ Finally (-)-cyclocolorenone (71) showed antibacterial activity against several Gram-positive bacteria and, at higher concentrations, against Gram-negative bacteria and also inhibited the growth of the fungi Curvularia lunata, Chaetomium cochliodes and Chaetomium spinosum, but not of Aspergillus flavus. ${ }^{45}$ 15-hydroxyspathulenol (72) was examined for antimicrobial activity against Gram-positive and Gram-negative bacteria Pseudomonas aeruginosa, $E$. coli and the yeast $C$. albicans but it was inactive. ${ }^{46}$ Finally, 3-acetoxyspathulenol (73) was tested for its antimicrobial activity against two bacteria (E. coli and Bacillus megaterium) 
and four fungi (Eurotium repens, Fusarium oxysporum, Microbotryum violacea and Mycotypha microspora) but again it was inactive. ${ }^{47}$ In contrast to spathulenol (51), compounds 72 and 73 possess oxygenated substituents either at the C-3 or C-15 positions which may be involved in the loss of antimicrobial activity of these compounds. In these compounds, the distance between the hydrophilic group and the hydrophobic dimethylcyclopropane ring appears to affect their antimicrobial activity.
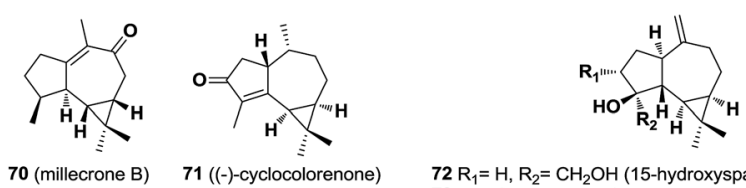

$72 \mathrm{R}_{1}=\mathrm{H}, \mathrm{R}_{2}=\mathrm{CH}_{2} \mathrm{OH}$ (15-hydroxyspathulenol) $73 R_{1}=O A c, R_{2}=$ Me (3-acetoxyspathulenol)

2.2.3 Antiviral activity. Macrocarpals A-C (59-61) showed significant inhibitory activity of HIV-RTase ${ }^{48}$ whereas 3-acetoxyspathulenol (73) was inactive. ${ }^{47}$ Euglobal-V (74) exhibited remarkable inhibitory effects on the Epstein-Barr virus. ${ }^{49}$ On the other hand, arvoside B (75) and related ledol glycosides 7680 exhibited antiviral activity against the vesicular stomatitis virus, arvoside B (75) being the most effective. ${ }^{\mathbf{5 0}}$
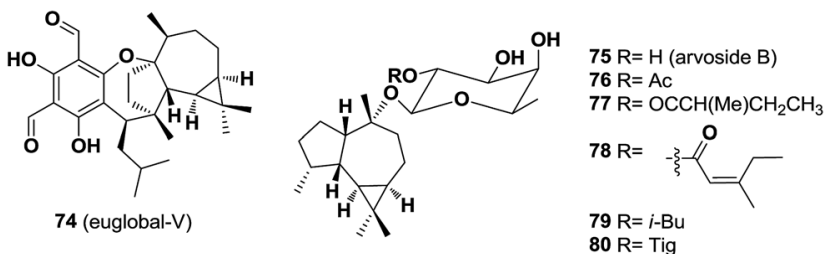

2.2.4 Cytotoxic activity. Allo-aromadendrane-10 $\beta, 14$-diol (57) was evaluated against Hep2 human larynx carcinoma cells and inhibited cellular growth. ${ }^{\mathbf{5 1}}$ For their part, macrocarpals A and $\mathrm{B}(59$ and 60) and eucalyptin A (81) exhibited inhibition on $\mathrm{HGF} / \mathrm{c}-\mathrm{Met}$ axis, with eucalyptin A (81) showing the most potent inhibition. ${ }^{52}$ Furthermore, eucalyptol D (82) which is a 3,5-diformyl-isopentyl phloroglucinol-coupled aromadendrane and which possesses an unusual seven-membered ring with an ether bridge between $\mathrm{C}-2$ of the aromadendrane moiety and C2 of the aromatic unit, exhibited significant in vitro cytotoxicity against the human cancer cell lines Huh-7, Jurkat, BGC-823 and KE-97.53 Epipolasinthiourea-B (83) showed moderate cytotoxic activity in vitro against $\mathrm{L} 1210$ cells $^{54}$ and psiguadial A (84) exhibited potent inhibitory effects on the growth of human hepatoma cells. ${ }^{55}$ Psidial B (85) was evaluated against several human cancer cell lines including A-2780, HCT-8, Bel-7402, A549 and BGC-823. ${ }^{56}$ Lochmolins A-D (86-89) and lochmolins E, F $(\mathbf{9 0}, 91)$ were evaluated against the proliferation of a limited panel of cancer cell lines, including HeLa, SK-Hep1 and B-16 carcinoma cells. ${ }^{57}$ The results showed that all these compounds were not cytotoxic toward these three cancer cell lines. Natural products $\mathbf{9 2}$ and $\mathbf{9 3}$ were evaluated for their cytotoxic effects against A-549 and U-2 OS cell lines ${ }^{58}$ whilst the cytotoxicity of compounds 94 and 95 against A-735 and cervical carcinoma HeLa cell lines was also examined as well by an MTT essay. ${ }^{38}$ Unfortunately they did not exhibit cytotoxicity.
Similarly, compounds $\mathbf{9 6} \mathbf{- 9 8}$ were not cytotoxic to P-388 and HT-29 cells. $^{59}$
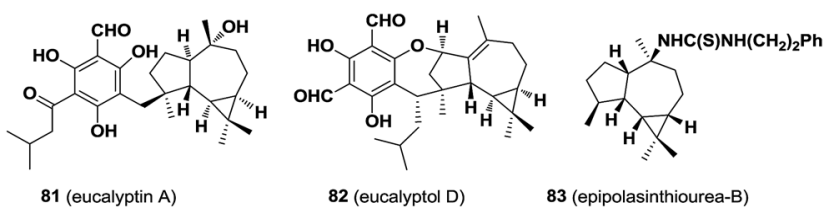

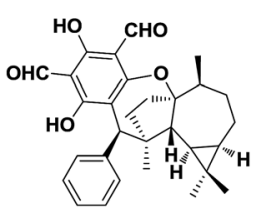

84 (psiguadial A)

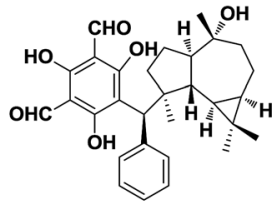

85 (psidial B)

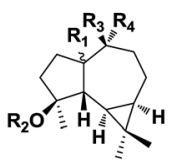

$87 \mathrm{R}_{1}=\alpha-\mathrm{H}, \mathrm{R}_{2}=\mathrm{Et}, \mathrm{R}_{3}=\mathrm{Me}, \mathrm{R}_{4}=\mathrm{OH}$ (lochmolin $\mathrm{B}$ ) $90 \mathrm{R}_{1}=\alpha-\mathrm{OOH}, \mathrm{R}_{2}=\mathrm{H}, \mathrm{R}_{3}, \mathrm{R}_{4}==\mathrm{CH}_{2}$ (lochmolin E)

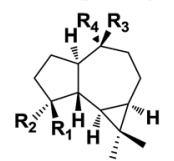

$92 \mathrm{R}_{1}=\mathrm{R}_{3}=\mathrm{OH}, \mathrm{R}_{2}=\mathrm{Me}, \mathrm{R}_{4}=\mathrm{CH}_{2} \mathrm{OH}$ $93 \mathrm{R}_{1}=\mathrm{R}_{4}=\mathrm{OH}, \mathrm{R}_{2}=\mathrm{Me}, \mathrm{R}_{3}=\mathrm{CH}_{2} \mathrm{OH}$ $94 R_{1}=R_{4}=O H, R_{2}=R_{3}=M e$ $95 R_{1}=R_{3}=M e, R_{2}=R_{4}=O H$ $89 \mathrm{R}_{1}=\beta-\mathrm{OOH}, \mathbf{R}_{2}=\mathrm{H}, \mathrm{R}_{3}, \mathrm{R}_{4}==\mathrm{CH}_{2}$ (lochmolin $\mathrm{D}$ )

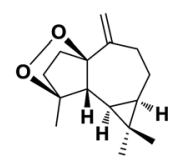

86 (lochmolin A)

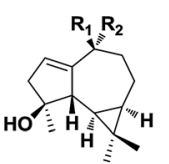

$88 \mathrm{R}_{1}=\mathrm{OOH}, \mathrm{R}_{2}=\mathrm{Me}($ lochmolin C) $91 \mathrm{R}_{1}=\mathrm{Me}, \mathrm{R}_{2}=\mathrm{OH}$ (lochmolin $\mathrm{F}$ )

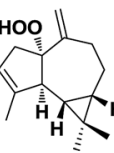

$96 \quad \begin{aligned} & 97 \mathrm{R}_{1}=\mathrm{Me}, \mathrm{R}_{2}=\mathrm{OH} \\ & 98 \mathrm{R}_{1}, \mathrm{R}_{2}==\mathrm{CH}_{2}\end{aligned}$
The vast majority of cytotoxic aromadendranes $(\mathbf{5 9}, \mathbf{6 0}, \mathbf{8 1}$, 82, 84, and 85) possess a phloroglucinol moiety coupled to an aromadendrane-type skeleton in which the presence of a methyl group at the C-4 and C-10 positions, the gem-dimethylcyclopropyl unit and a $\beta$-hydrogen at C-5 are common in all of them (Fig. 3). These more rigid sesquiterpenes might be acting as biological carriers ensuring that the pharmacophore can cross various barriers and reach the active site. The common substituents of these aromadendranes are highlighted below. To our knowledge, phloroglucinol-coupled ent-aromadendranes have not been found in nature.

2.2.5 Other activities. Compounds obtained from plants of the genus Eucalyptus or from microorganisms, such as macrocarpals A and B (59 and 60), isolated from Eucalyptus globulus, have been shown to be useful as CNS activity modulators e.g. in the treatment of depression, for lifting mood and/or for increasing other behavioural activities. ${ }^{60}$ Macrocarpals A-C (59-

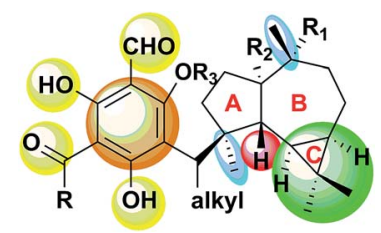

Fig. 3 Common parts of cytotoxic aromadendranes. 
61) also showed significant inhibitory activity of aldose reductase. ${ }^{61}$

Allo-aromadendrane 68 caused a reduction in the growth of cress seeds and stimulated wood and shoot growth in lettuce at low concentration ${ }^{\mathbf{4 2}}$ whereas cyclocolorenone (71) showed growth inhibitory activity against etiolated wheat coleoptiles and phytotoxicity against green-house grown corn, bean and tobacco plants. ${ }^{45}$ Globulol (99) exhibited weak activity against the germination of cress seeds. ${ }^{62}$

Euglobal-V (74) showed granulation inhibition in the fertile egg test indicating anti-inflammatory activity. ${ }^{63}$ Psidial B (85) showed activity towards protein tyrosine phosphatase $1 \mathrm{~B}$ (PTP1B) with inhibition rates of $61.7 \%$ in $10 \mu \mathrm{M}^{56}$ The antiinflammatory activities of lochmolins A-D (86-89) against the accumulation of pro-inflammatory iNOS and COX-2 proteins in RAW264.7 macrophage cells have been evaluated and all of them were found to inhibit the accumulation of the LPSinduced pro-inflammatory COX-2 protein in RAW264.7 macrophage cells. $^{57}$

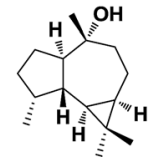

99 (globulol)

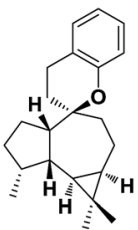

100 (tanzanene)
3-Acetoxyspathulenol (73) was tested for its effects towards a nematode (Caenorhabditis elegans), the green alga Chlorella fusca, brine shrimp (Artemia salina), and p56lck tyrosine kinase but in all of the applied test systems no positive activities were observed. ${ }^{47}$ Furthermore, the anti-inflammatory activities of lochmolins $\mathrm{E}$ and $\mathrm{F}$ (90 and $\mathbf{9 1}$ ) against the accumulation of proinflammatory iNOS and COX-2 proteins in RAW264.7 macrophage cells were evaluated but they did not show activity. ${ }^{57}$ Compounds 92 and 93 were evaluated for their antioxidant effects on $\mathrm{H}_{2} \mathrm{O}_{2}$ production in $\mathrm{H} 9 \mathrm{c} 2$ cardiac muscle cells, and their anti-inflammatory effects on lipopolysaccharide-induced
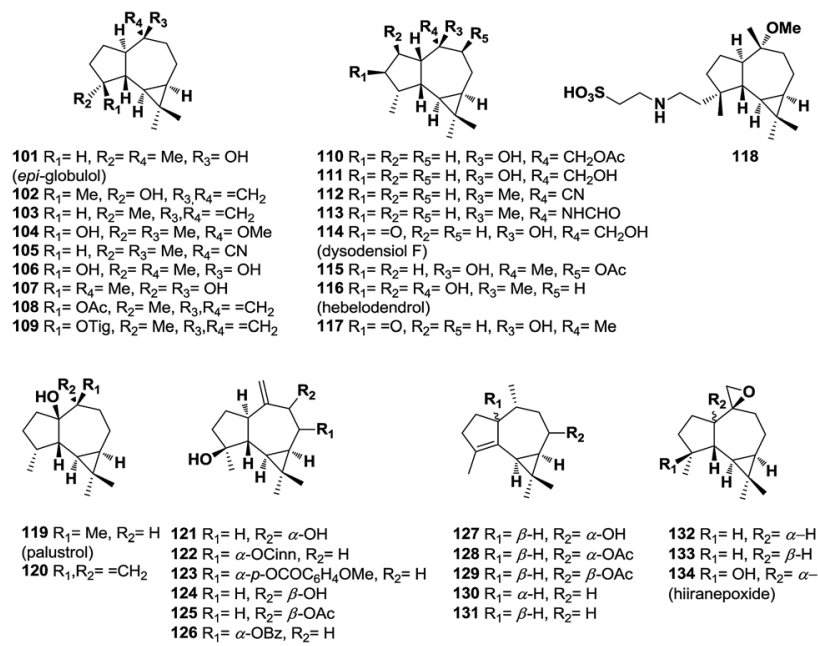

$27 \mathrm{R}_{1}=\beta-\mathrm{H}, \mathrm{R}_{2}=\alpha-\mathrm{OH}$ $128 \mathrm{R}_{1}=\beta-\mathrm{H}, \mathrm{R}_{2}=\alpha-\mathrm{OAC}$ $130 \mathrm{R}_{1}=\alpha-\mathrm{H}_{1} \mathrm{R}_{2}=\mathrm{H}$ $131 \mathrm{R}_{1}=\beta-\mathrm{H}, \mathrm{R}_{2}=\mathrm{H}$ nitric oxide production in both RAW 264.7 and BV-2 cells. $^{58}$ Tanzanene (100) was tested in the growth inhibition essay of $P$. falciparum in vitro but it showed no activity. ${ }^{64}$
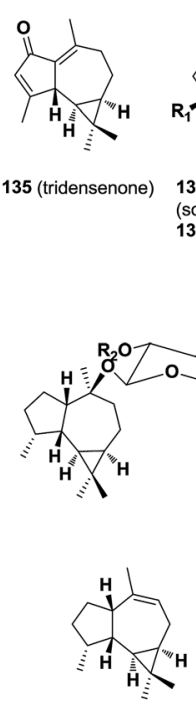

148

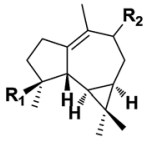

$136 R_{1}=H, R_{2}==O$ (squamulosone)
$137 \mathrm{R}_{1}=\mathrm{OH}, \mathrm{R}_{2}=\mathrm{H}$

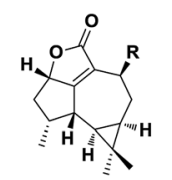

$138 \mathrm{R}=\mathrm{H}$ $139 \mathrm{R}=\mathrm{OH}$
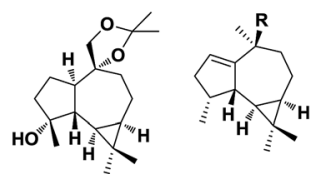

140

$141 \mathrm{R}=\mathrm{OH}$ $142 \mathrm{R}=\mathrm{H}$

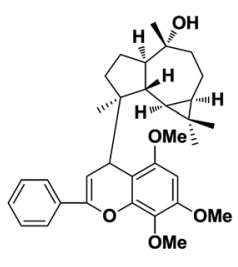

147 (fissistigmatin D)

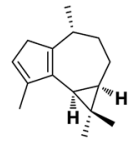

149
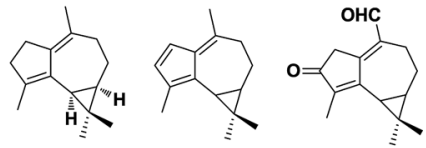

150151 (fulfulvene)

152

151 (fulfulvene) $\quad 152$

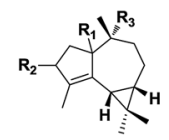

$166 \mathrm{R}_{1}=\alpha-\mathrm{H}, \mathrm{R}_{2}=\mathrm{R}_{3}=\mathrm{H}$ $167 \mathrm{R}_{1}=\alpha-\mathrm{H}, \mathrm{R}_{2}=\mathrm{H}, \mathrm{R}_{3}=\mathrm{OH}$ $168 \mathrm{R}_{1}=\beta-\mathrm{OH}, \mathrm{R}_{2}==0, \mathrm{R}_{3}=\mathrm{H}$ $169 \mathrm{R}_{1}=\alpha-\mathrm{OH}, \mathrm{R}_{2}==\mathrm{O}, \mathrm{R}_{3}=\mathrm{H}$ $170 \mathrm{R}_{1}=\alpha-\mathrm{H}, \mathrm{R}_{2}==\mathrm{O}, \mathrm{R}_{3}=\mathrm{H}$
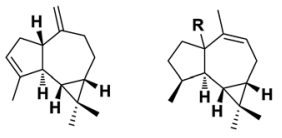

179

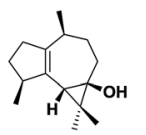

186

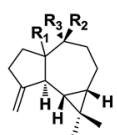

$171 \mathrm{R}_{1}=\beta-\mathrm{H}, \mathrm{R}_{2}=\mathrm{Me}, \mathrm{R}_{3}=\mathrm{OH}$ $172 \mathrm{R}_{1}=\alpha-\mathrm{H}, \mathrm{R}_{2}, \mathrm{R}_{3}==\mathrm{CH}_{2}$ $172 \mathrm{R}_{1}=\alpha-\mathrm{H}, \mathrm{R}_{2}, \mathrm{R}_{3}==\mathrm{CH}_{2}$
$173 \mathrm{R}_{1}=\beta-\mathrm{OH}, \mathrm{R}_{2}, \mathrm{R}_{3}==\mathrm{CH}_{2}$

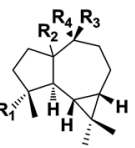

$159 \mathrm{R}_{1}=\mathrm{R}_{3}=\mathrm{OH}, \mathrm{R}_{2}=\beta-\mathrm{H}, \mathrm{R}_{4}=\mathrm{Me}$ $161 \mathrm{R}_{1}=\mathrm{H}_{1} \mathrm{R}_{2}=\alpha+\mathrm{H}_{1} \mathrm{R}_{3}, \mathrm{R}_{4}=\mathrm{CH}_{2}$

$162 \mathrm{R}_{1}=\mathrm{R}_{4}=\mathrm{H}, \mathrm{R}_{2}=\beta-\mathrm{NHCHO}, \mathrm{R}_{3}=\mathrm{Me}$ $163 \mathrm{R}_{1}=\mathrm{R}_{4}=\mathrm{H}, \mathrm{R}_{2}=\beta-\mathrm{NC}, \mathrm{R}_{3}=\mathrm{Me}$ $164 \mathrm{R}_{1}=\mathrm{R}_{4}=\mathrm{H}, \mathrm{R}_{2}=\beta$-NCS, $\mathrm{R}_{3}=\mathrm{Me}$

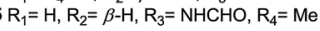

\section{3 ent-1,10-Secoaromadendranes (structures 191-195)}

Although a number of ent-1,10-secoaromadendrane-type sesquiterpenes have been isolated from Mylia species of 
liverworts and the liverwort Lepicolea ochroleuca ${ }^{65-67}$ the biological activities of these compounds have not been investigated.

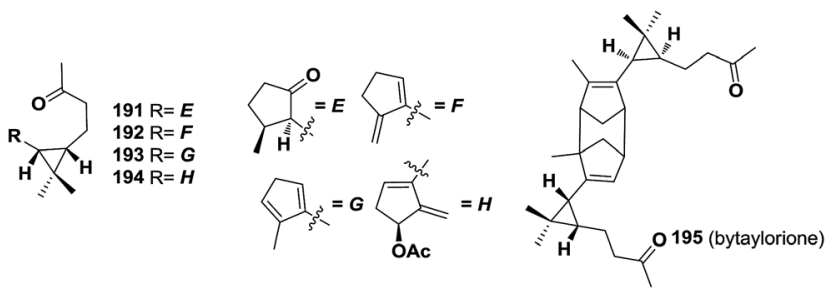

\subsection{2,3-Secoaromadendranes (structures 196-226)}

The ent-2,3-secoaromadendrane-type sesquiterpenes are widely distributed in liverworts such as members of Plagiochilaceae and H. planus. ${ }^{\mathbf{6 8 , 6 9}}$ The presence of (-)-bicyclogermacrene in a Plagiochila species led to the proposal of a possible route for the biosynthesis of ent-2,3-secoaromadendrane lactones and hemiacetals from this metabolite. ${ }^{70}$ The pungent substances of the Plagiochilaceae are ent-2,3-secoaromadendrane-type sesquiterpenes which have shown different biological activities.

Plagiochiline A (196) is an ent-secoaromadendrane-type sesquiterpene hemiacetal which was isolated from Plagiochila species ${ }^{71-73}$ that showed cytotoxic activity against P-388 murine leukemia tumor cells, ${ }^{74} \mathrm{~KB}$ cells ${ }^{75}$ and which exhibited strong antifeedant activity against the African army worm Spodoptera exempta. ${ }^{76}$ Plagiochiline C (198) showed significant antiplatelet effects on the arachidonate and collagen induced aggregations of washed rabbit platelets. ${ }^{77}$ When plagiochiline A and M (196 and 200) were incorporated into the larval diet they reduced the larval growth of Spodoptera frugiperda. As compound 205 underwent rapid decomposition after incorporation into the larval diet of $S$. frugiperda, its effects could not be evaluated. ${ }^{71}$ Treatment with plagiochiline $\mathbf{M}$ (200) also produced abdomen and wing malformation in adult insects preventing mating. ${ }^{71}$ Plagiochilal B (207) showed neurotrophic properties. It exhibits not only acceleration of neurite sprouting but also enhancement of choline acetyltransferase activity on a neuronal cell culture of the cerebral hemisphere of a fetal rat. However, plagiochilines J, K and plagiochilide (209-211) showed no neurotrophic activity. ${ }^{70}$ This fact could be explained by the presence of a rigid six-membered ring instead of the corresponding open chain dialdehyde. The biological activity of dialdehydes is often associated with the formation of rings with amines.

On the other hand, plagiochiline A (196) inhibited the germination of rice and wheat ${ }^{78}$ whereas plagiochiline C (198), ovalifolienal (212), ovalifolienalone (213) and ovalimethoxy I and II (214 and 215) inhibited the growth of the leaves and roots of rice seedlings. ${ }^{79}$ Finally compound 226 is the first compound with a 2,3-secoaromadendrane-type skeleton which has been isolated from a culture of basidiomycete Agrocybe salicacola. However the biological activity has not been tested to our knowledge. ${ }^{80}$

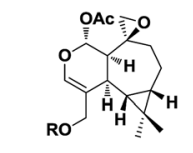

$196 R=A c$ (plagiochiline $A)$
$197 R=H$

$198 \mathrm{R}_{1}=\mathrm{CH}_{2} \mathrm{OAC}, \mathrm{R}_{2}=\mathrm{R}_{3}=\mathrm{H}$ (plagiochiline $\mathrm{C}$ ) $200 R_{1}=$ COOMe, $R_{2}=R_{3}=H$ (plagiochiline $L$ ) $201 R_{1}=M e, R_{2}=R_{3}=H$ $202 \mathrm{R}_{1}=\mathrm{CH}_{2} \mathrm{OAc}, \mathrm{R}_{2}=\mathrm{OAc}, \mathrm{R}_{3}=\mathrm{H}$ $203 \mathrm{R}_{1}=\mathrm{CH}_{2} \mathrm{OAC}, \mathrm{R}_{2}=\mathrm{H}, \mathrm{R}_{3}=\mathrm{OAC}$ (6 $\alpha$-acetoxyovalifoliene) 204 $\mathrm{R}_{1}=\mathrm{CH}_{2} \mathrm{OH}, \mathrm{R}_{2}=\mathrm{R}_{3}=\mathrm{H}$ (4-O-deacetylplagiochiline C)
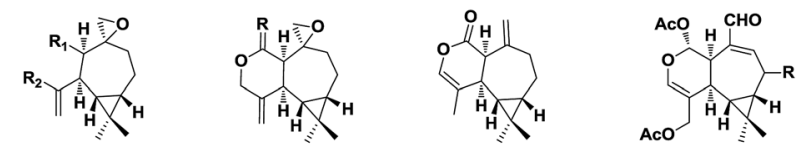

$207 \mathrm{R}_{1}=\mathrm{R}_{2}=\mathrm{CHO}$ (plagiochilal B)
$208 \mathrm{R}_{1}=\mathrm{R}_{2}=\mathrm{CH}_{2} \mathrm{OA}$

$209 \mathrm{R}=\mathrm{O}$ (plagiochiline J) 211 (plagiochilide) $212 \mathrm{R}=\mathrm{H}((+)$-ovalifolienal) $210 \mathrm{R}=\alpha-\mathrm{OH}, \mathrm{H}$ (plagiochiline K)

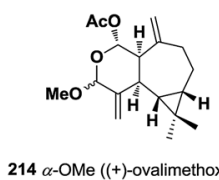
$214 \alpha$-OMe ((+)-ovalimethoxy I)
$215 \beta$-OMe ((+)-ovalimethoxy II)

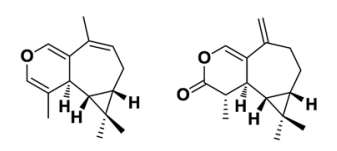

216 (plagiochiline N) 217 (plagiochiline Q)
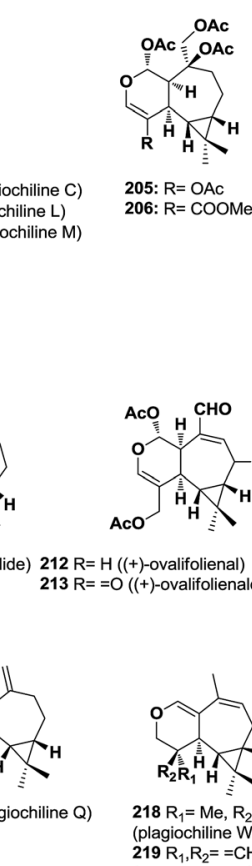

205: $R=O A C$ 206: $R=C O O M$
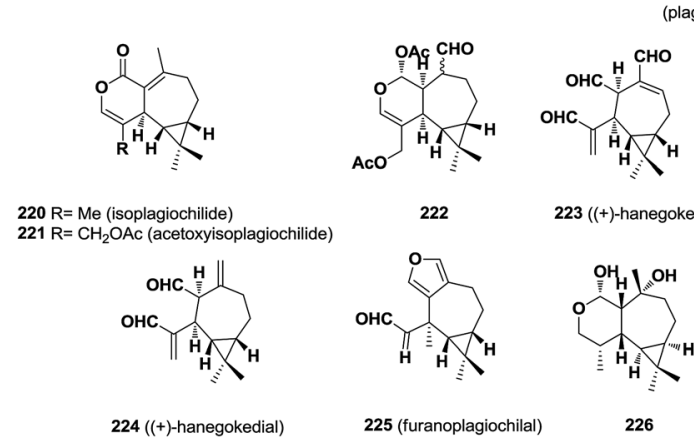
(plagiochiline $W$ ) $219 \mathrm{R}_{1}, \mathrm{R}_{2}==\mathrm{CH}_{2}$
(plagiochiline $\mathrm{X}$ )

$224((+)$-hanegokedial)

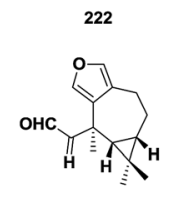

$223((+)$-hanegoketrial)

225 (furanoplagiochilal)

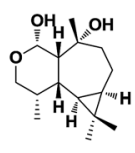

226

\section{5 ent-5,10-Cycloaromadendranes (structures 227-231)}

ent-5,10-Cycloaromadendranes are fused tetracyclic sesquiterpenes with two cyclopropane rings which have only been isolated from liverworts of the Calypogeia, Saccogyna and Mylia species. ${ }^{66,81-83}$ As far as we know the biological activities of these compounds have not been investigated.
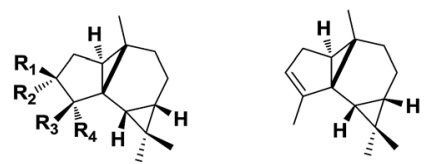

$$
\begin{aligned}
& 227 R_{1}=R_{2}=H, R_{3}, R_{4}==C_{2} \quad 231 \text { (anastreptene) } \\
& 228 R_{1}=O H, R_{2}=H, R_{3}, R_{4}==C_{2} \\
& 229 R_{1}, R_{2}==O, R_{3}=H, R_{4}=C_{3} \\
& 230 R_{1}, R_{2}==O, R_{3}, R_{4}=C_{2}
\end{aligned}
$$

\subsection{Lepidozanes and bicyclogermacrenes (structures 232-} 283)

Bicyclogermacrenes, which are found in higher plants, have a cis-fused cyclopropane ring whereas stereoisomeric lepidozanes are found in liverworts and marine organisms, which possess a trans-fused cyclopropane ring. ${ }^{15}$ This stereochemistry seems to determine the biological activity of these compounds. Whereas 
the fungistatic, allelopathic, cytotoxic and inhibitory activities of acetylcholinesterase have been described for bicyclogermacrenes, only the cytotoxic activity has been reported for the lepidozanes.

2.6.1 Cytotoxic activity. The phloroglucinol-terpene adducts are a group of secondary metabolites with interesting bioactive structures that are unique to plants of the Myrtaceae family, especially the Eucalyptus species. ${ }^{\mathbf{8 4 - 8 6}}$ Thus the euglobals are acylphloroglucinol-terpenes. Euglobal III (232) is one of the most active and it has a wide variety of biological activities. Among them it exhibited remarkable antitumor promoting effects on mouse skin tumors in an in vivo carcinogenesis test. $^{\mathbf{8 7 , 8 8}}$ On the other hand, lepidozanes 233-238 exhibited cytotoxicity against murine melanoma cells. Compounds 233 and 236 have an allylic hydroperoxymethylene group which is rare in natural products and they exhibited the strongest activity. ${ }^{89}$ Finally, bicyclogermacrenes 239 and 240 showed significant cytotoxicity toward HepG2 and HepG2/ADM cells. ${ }^{\mathbf{9 0}}$

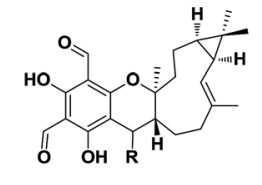

$232 \mathrm{R}=\alpha$-isobutyl (euglobal-III)
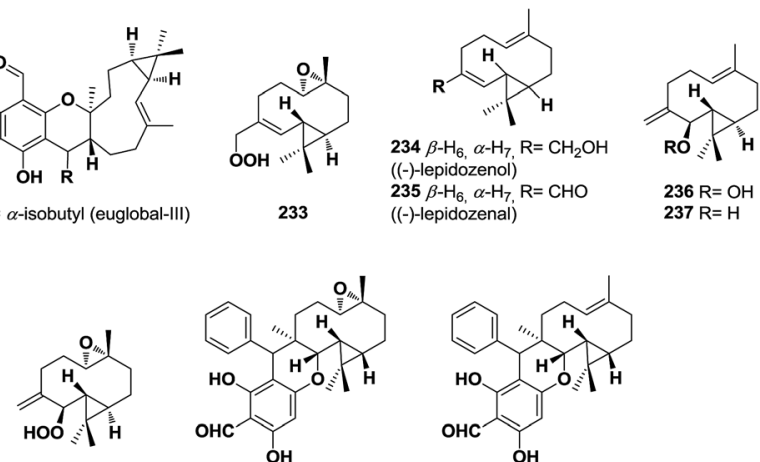

238

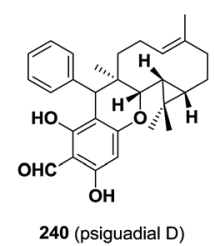

240 (psiguadial D)

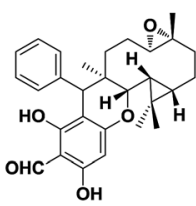

239 (psiguadial C)
2.6.2 Other activities. Euglobal-III (232), euglobal-IVb (241) and euglobal-VII (242) possessed a potent granulation inhibition activity ${ }^{\mathbf{1 1 9 2}}$ whereas (-)-isobicyclogermacrenal (243), isolated from the liverwort Lepidozea vitrea, inhibited the growth of
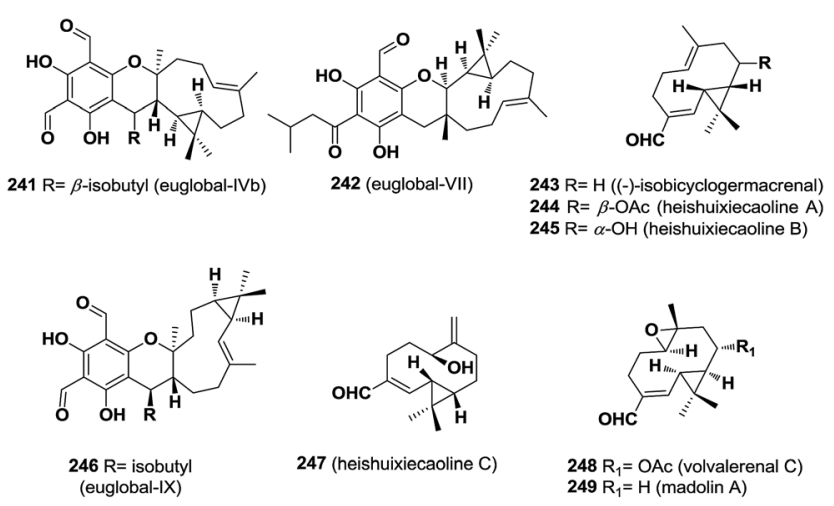

247 (heishuixiecaoline C)

$48 \mathrm{R}_{1}=\mathrm{OAC}$ (volvalerenal $\mathrm{C}$ ) $249 \mathrm{R}_{1}=\mathrm{H}$ (madolin $\mathrm{A}$ )

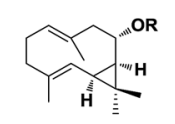

$250 \mathrm{R}=\mathrm{H}$ (partheniol) $251 \mathrm{R}=$ Cinn (guayulin $\mathrm{A})$

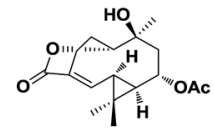

252 (valerianin E) rice. ${ }^{93}$ Euglobal-III (232) has also shown strong inhibitory effects on the activation of the Epstein-Barr virus. ${ }^{49}$ The essential moiety for this activity was considered to be the presence of acylphloroglucinol structure. Thereby, euglobal-IX (246) inhibited the catalytic activity of CYP3A4. ${ }^{94}$ On the other hand, the protective effect of heishuixiecaoline A-C (244, 245 and 247) and volvalerenal $\mathrm{C}$ (248) was investigated on the neurotoxicity of PC12 cells induced by amyloid-beta $\left(\mathrm{A} \beta_{25-25}\right)$. They were seen to afford protection against $\mathrm{A} \beta$-induced toxicity in PC 12 cells. $^{53}$ Finally, the bicyclogermacrene madolin A (249) showed an inhibitory activity on acetylcholinesterase ${ }^{95,96}$ whereas partheniol (250), ${ }^{97}$ guayulin A (251) ${ }^{98}$ and valerianin E (252) ${ }^{99}$ showed fungistatic activity against the growth of Aspergillus niger, allergenic activity and antidepressant activity, respectively.

Volvalerenals A, B, D and E (253, 254, 257 and 258) and volvalerenic acids A-C (260, 261 and 263) were examined for acetylcholinesterase inhibitory activity, but all were inactive at $100 \mu \mathrm{M}$ unlike madolin A (249). ${ }^{95}$ The presence of an epoxide between $\mathrm{C}-1$ and $\mathrm{C}-10$ and the absence of functionality at C-14 might be key features for the acetylcholinesterase inhibitory activity of madolin A (249). On the other hand, valerianins A and B (264 and 265) were evaluated for their antidepressant activity based on recording the total duration of immobility of mice in a forced swim test. In contrast to compound 252, they showed no antidepressant activity. ${ }^{99}$ The lactone ring of compound 252 might be involved in the biological activity because the greater rigidity it imposes enables the compound to cross the barriers and reach the site of activity. Finally, guayulin B (266) does not exhibit significant allergenic activity contrary to guayulin A (251). ${ }^{98}$ This suggests that the substituent at C-8 might play a crucial role in the biological activity of these compounds.

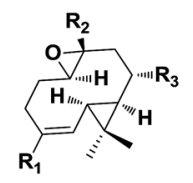

$253 \mathrm{R}_{1}=\mathrm{CHO}, \mathrm{R}_{2}=\mathrm{CH}_{2} \mathrm{OAC}, \mathrm{R}_{3}=\mathrm{H}$ (volvalerenal A)

$254 \mathrm{R}_{1}=\mathrm{R}_{2}=\mathrm{CHO}, \mathrm{R}_{3}=\mathrm{H}$ (volvalerenal $\mathrm{B}$ )

$255 \mathrm{R}_{1}=\mathrm{COOH}, \mathrm{R}_{2}=\mathrm{Me}, \mathrm{R}_{3}=\mathrm{H}$ (madolin $\mathrm{B}$ )

$256 R_{1}=R_{3}=H, R_{2}=M e$ (madolin $C$ )

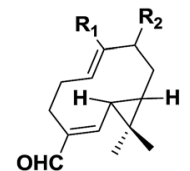

$257 \alpha-\mathrm{H}_{6}, \alpha-\mathrm{H}_{7}, \mathrm{R}_{1}=\mathrm{Me}, \mathrm{R}_{2}=\alpha-\mathrm{OH}$ (volvaleranals $\mathrm{D}$ ) $258 \beta-\mathrm{H}_{6}, \alpha-\mathrm{H}_{7}, \mathrm{R}_{1}=\mathrm{CH}_{2} \mathrm{OAc}, \mathrm{R}_{2}=\mathrm{H}$ (volvaleranals $\mathrm{E}$ ) $259 \alpha-\mathrm{H}_{6}, \alpha-\mathrm{H}_{7}, \mathrm{R}_{1}=\mathrm{Me}, \mathrm{R}_{2}=\mathrm{H}$

\subsection{Maalianes (structures 284-305)}

Although the maalianes have been isolated from a range of plants, such as liverworts, marine sponges, soft corals and bacteria, they are not abundant in nature. Furthermore, to our knowledge little biological activity has been reported. Compound 284 and epipolasin-A (285), isolated from Cadlina luteomarginata, were toxic to the fish Carussius auratus at $10 \mu \mathrm{g}$ $\mathrm{mg}^{-1}$ in a food pellet. ${ }^{100}$ Epipolasin-A (285) showed in vitro antimalarial activity. ${ }^{101}$ Epipolasinthiourea-A (286) showed moderate cytotoxic activity in vitro. ${ }^{54}(1 R)$-Bromo-ent-maaliol (293) is a cytotoxic halogenated maaliane isolated from the calcareous green algae Neomeris annulata. The cytotoxic activity of the ent-maaliane $\mathbf{2 9 3}$ was indicated by its toxicity to brine 

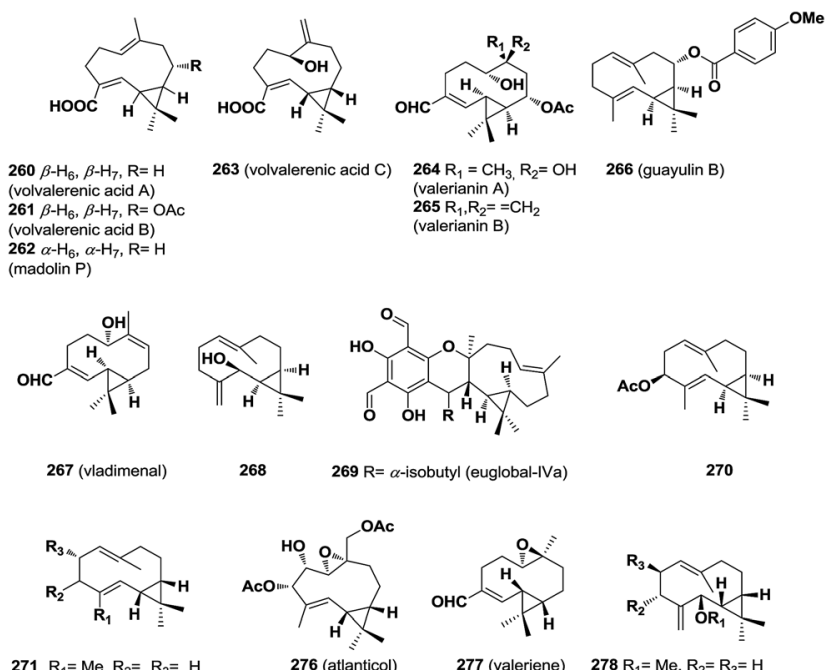

270

$271 \mathrm{R}_{1}=\mathrm{Me}, \mathrm{R}_{2}=\mathrm{R}_{3}=\mathrm{H}$

$272 \mathrm{R}_{1}=\mathrm{Me}, \mathrm{R}_{2}=\beta$-OAc, $\mathrm{R}_{3}=\mathrm{H}$

$273 \mathrm{R}_{1}=\mathrm{Me}, \mathrm{R}_{2}=\beta-\mathrm{OH}, \mathrm{R}_{3}=\mathrm{H}$

$274 \mathrm{R}_{1}=\mathrm{CH}_{2} \mathrm{OMe}, \mathrm{R}_{2}=\mathrm{R}_{3}=\mathrm{H}$

$275 \mathrm{R}_{1}=\mathrm{Me}, \mathrm{R}_{2}=\alpha-\mathrm{OAc}, \mathrm{R}_{3}=\mathrm{OH}$

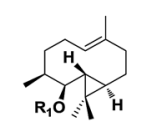

$280 \mathrm{R}=\mathrm{Me}$
$281 \mathrm{R}=\mathrm{H}$

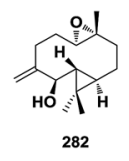

(N)

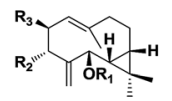

$278 R_{1}=M e, R_{2}=R_{3}=H$
$279 R_{1}=H, R_{2}=O A c, R_{3}=1$

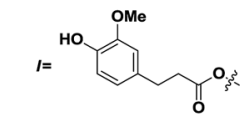

282

277 (valeriene)

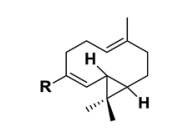

$283 \alpha-\mathrm{H}_{6}, \beta-\mathrm{H}_{7}, \mathrm{R}=\mathrm{Me}$

shrimp. ${ }^{\mathbf{1 0 2}}$ Finally, maaliane 294, isolated from Acanthella pulcherrima, has been described as an antimicrobial compound. ${ }^{36}$ This compound is enantiomeric to epipolasin-A (285), and thus provides the first reported occurrence of an enantiomorphic pair of maalianes. ${ }^{36}$

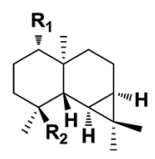

$284 R_{1}=H, R_{2}=N C$ $285 \mathrm{R}_{1}=\mathrm{H}, \mathrm{R}_{2}=\mathrm{NCS}$ (epipolasin-A) $286 \mathrm{R}_{1}=\mathrm{H}, \mathrm{R}_{2}=\mathrm{NHC}(\mathrm{S}) \mathrm{NH}\left(\mathrm{CH}_{2}\right)_{2} \mathrm{Ph}$ (epipolasinthiourea-A) $287 \mathrm{R}_{1}=\mathrm{H}, \mathrm{R}_{2}=\mathrm{OH}$ (maaliol) $288 \mathrm{R}_{1}=\mathrm{OGlc}, \mathrm{R}_{2}=\mathrm{OH}$ $289 \mathrm{R}_{1}=\mathrm{NC}, \mathrm{R}_{2}=\mathrm{H}$ $290 \mathrm{R}_{1}=\mathrm{NCS}, \mathrm{R}_{2}=\mathrm{H}$ $291 \mathrm{R}_{1}=\mathrm{HNCHO}, \mathrm{R}_{2}=\mathrm{H}$ $292 \mathrm{R}_{1}=\mathrm{R}_{2}=\mathrm{OH}$

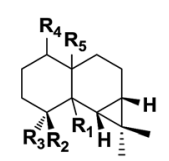

$293 \mathrm{R}_{1}=\alpha-\mathrm{H}, \mathrm{R}_{2}=\mathrm{Me}, \mathrm{R}_{3}=\mathrm{OH}, \mathrm{R}_{4}=\beta-\mathrm{Br}, \mathrm{R}_{5}=\beta-\mathrm{Me}$ ((1R)-bromo-ent-maaliol)

$294 R_{1}=R_{4}=H, R_{2}=M e, R_{3}=N C S, R_{5}=\beta$-Me $295 \mathrm{R}_{1}=\alpha-\mathrm{H}, \mathrm{R}_{2}, \mathrm{R}_{3}==\mathrm{CH}_{2}, \mathrm{R}_{4}=\mathrm{H}, \mathrm{R}_{5}=\beta$-Me $296 \mathrm{R}_{1}=\alpha-\mathrm{H}, \mathrm{R}_{2}=\mathrm{Me}, \mathbf{R}_{3}=\mathrm{OH}, \mathbf{R}_{4}=\mathrm{H}, \mathbf{R}_{5}=\beta-\mathrm{Me}$ $297 \mathrm{R}_{1}=\beta-\mathrm{H}, \mathrm{R}_{2}=\mathrm{H}, \mathrm{R}_{3}=\mathrm{Me}, \mathrm{R}_{4}=\alpha-\mathrm{OH}, \mathrm{R}_{5}=\alpha-\mathrm{Me}$ (avermitilol)

$298 \mathrm{R}_{1}=\mathrm{R}_{4}=\mathrm{H}, \mathrm{R}_{2}=\mathrm{OH}, \mathrm{R}_{3}=\mathrm{Me}, \mathrm{R}_{5}=\beta-\mathrm{Me}$ (ent-4-epi-maaliol)

$299 \mathrm{R}_{1}=\alpha-\mathrm{OH}, \mathrm{R}_{2}=\mathrm{Me}, \mathrm{R}_{3}=\mathrm{R}_{4}=\mathrm{H}, \mathrm{R}_{5}=\beta-\mathrm{Me}$ $300 \mathrm{R}_{1}=\alpha-\mathrm{H}, \mathrm{R}_{2}, \mathrm{R}_{3}==\mathrm{CH}_{2}, \mathrm{R}_{4}=\alpha-\mathrm{OH}, \mathrm{R}_{5}=\beta-\mathrm{Me}$

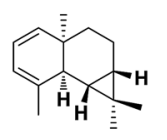

301

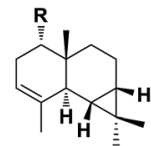

$302 \mathrm{R}=\mathrm{H}$ $303 \mathrm{R}=\mathrm{OAC}$

$304 \mathrm{R}=\mathrm{OH}$

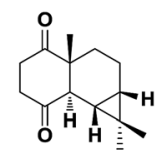

305 (madolin F)<smiles>C[C@@H]1CC[C@@H](C)[C@]2(O)CC[C@H]3[C@@H](C)[C@H]3[C@H]12</smiles>

306 (prostantherol)

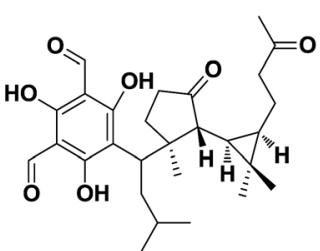

307 (eucalyptone)

2.8.2 Cytotoxic activity. Halichonadin E (308) is an unusual dimeric sesquiterpenoid with eudesmane and aromadendrane skeleta linked through a urea fragment. It showed activity against L1210 murine leukaemia and KB human epidermoid carcinoma cells in vitro. ${ }^{105}$ Anthoplalone (309) and noranthoplone (310) showed cytotoxic activity against B-16 murine melanoma cells ${ }^{\mathbf{8 9}}$ whilst neomeranol (311) is a cytotoxic halogenated sesquiterpene isolated from the algae Neomeris annulata $^{\mathbf{1 0 2}}$ Finally, compound $\mathbf{3 1 2}$ was assessed for its potential cytotoxicity against selected cancer cells. Unfortunately it was not cytotoxic to P-388 and HT-29 cells. ${ }^{59}$

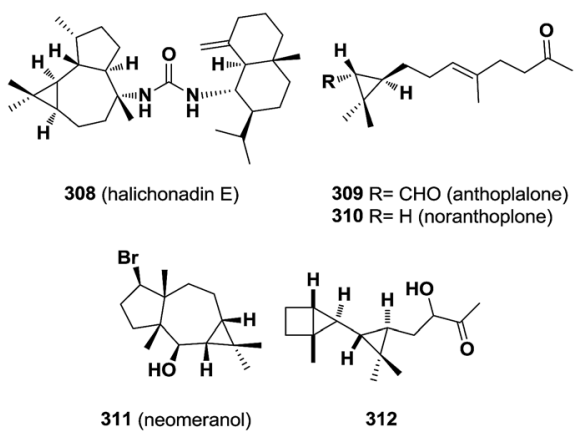

2.8.3 Other activities. Eucalyptone (307) exhibited an inhibitory effect on adherent water-insoluble glucan synthesis. ${ }^{104}$ Neomeranol (311) and (+)-vitrenal (313) have a potent inhibitory effect on the growth of plants ${ }^{\mathbf{1 0 2 , 1 0 6 - 1 0 8}}$ whereas nardoaristolone $\mathrm{B}$ (314) exhibited obvious protective effects on the injury of neonatal rat cardiomyocytes. ${ }^{22}$ Compounds 315318 were examined for their effects on enhancing the nerve growth factor (NGF). Compounds 316-318 showed enhancing activity. ${ }^{109}$ Furthermore, compound 318 induced neurite outgrowth in PC 12D cells. ${ }^{110}$ Finally, kunzeanone C (319) is an alkylated phloroglucinol metabolite from Kunzea ambigua that exhibited ichthyotoxic activity. ${ }^{111}$

\subsection{The biological role of the gem-dimethylcyclopropane unit in sesquiterpenes}

The presence of the gem-dimethylcyclopropyl group imposes a conformational rigidity on the part of the molecule to which it is attached. This in turn not only affects the chemistry of that part of the molecule but it can also affect the way in which the compound binds to specific receptors and hence it can

This section contains other sesquiterpenes that are not encompassed by any of the above groups and their biological activities.
2.8.1 Antimicrobial activity. Prostantherol (306) is an antimicrobial sesquiterpene which inhibits the Gram-positive Streptomyces scabies. ${ }^{\mathbf{1 0 3}}$ Eucalyptone (307) has shown antibacterial activity against the cariogenic bacteria Streptococcus species. ${ }^{104}$ 


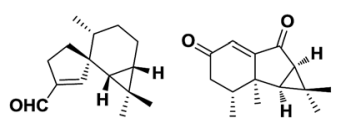
313 ((+)-vitrenal) 314 (nardoaristolone B) $\begin{aligned} & 317 \mathrm{R}_{1}=\mathrm{H}, \mathrm{R}_{2}=\mathrm{CH}_{2} \mathrm{O} \\ & \mathbf{3 1 8} \mathrm{R}_{1}=\mathrm{OAc}, \mathrm{R}_{2}=\mathrm{Me}\end{aligned}$
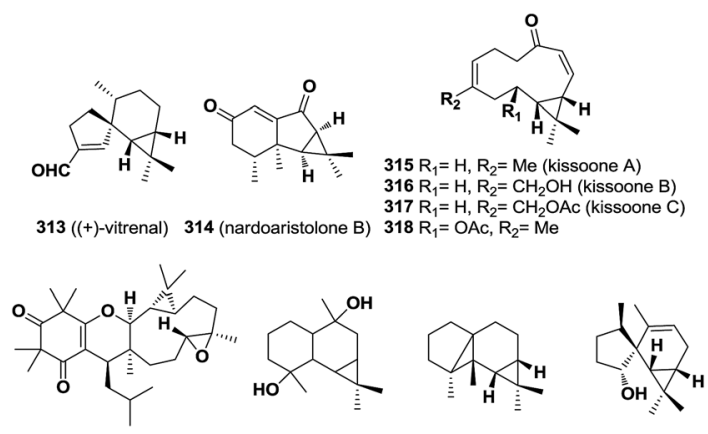

319 (kunzeanone C) 320 321 (tridensene)

322
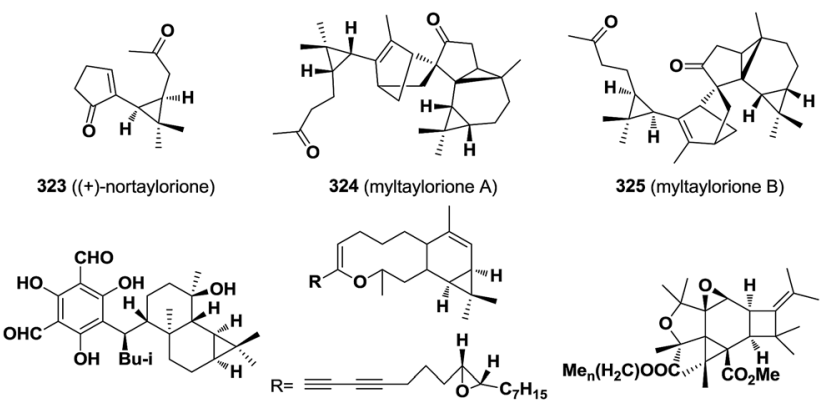

325 (myltaylorione B)

326 (macrocarpal L)

327 (ginsenoyne N) $328 n=16$ (stearyl-glutinopallal)
$329 n=14$ (palmityl-glutinopallal)
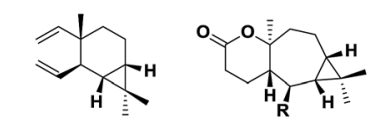

$331 \mathrm{R}=\mathrm{COOH}($ olvalerelactona $A)$

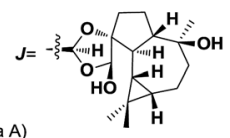

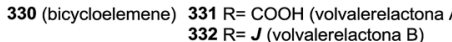

influence the biological activity. Furthermore the presence of the two methyl groups can provide a lipophilic face to the molecule whereas with the free rotation of an isopropyl group the position of the methyl groups are much more flexible. In general these natural products which display biological activity have oxygen functions that are distant from the lipophilic dimethylcyclopropane ring. We have carried out a literature search of the biologically activities of the corresponding isopropyl derivates of the biologically-active sesquiterpenes containing a gem-dimethylcyclopropane unit in order to find a link between the presence of the gem-dimethylcyclopropyl unit and the biological activity. Some examples found are shown below.

Firstly, the presence of the gem-dimethylcyclopropyl unit instead of an isopropyl unit can change the biological activity of different compounds. Thus, aromadendrane $\mathbf{5 5}$ is an antimicrobial agent while compound 333 showed cytotoxic activity. ${ }^{112}$ In the same way, aromadendrane $\mathbf{6 2}$ is an antimicrobial compound whereas its corresponding guaiane derivative $\mathbf{3 3 4}$ showed cytotoxic activity in vitro against L-1210 cells. ${ }^{113}$

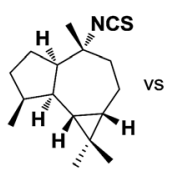

55

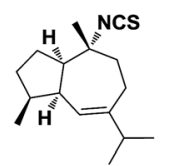

333

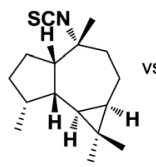

62

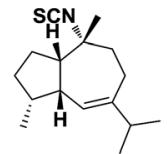

334
Secondly, sesquiterpenoids containing a gem-dimethylcyclopropane unit such as spathulenol (51), epipolasin B (56) and compound 69 have shown biological activity whereas their corresponding isopropyl derivatives nardol (335), ${ }^{14,115}$ axysothiocyanate-2 (336) ${ }^{116,117}$ and compound $337^{118,119}$ have not revealed any biological activity.

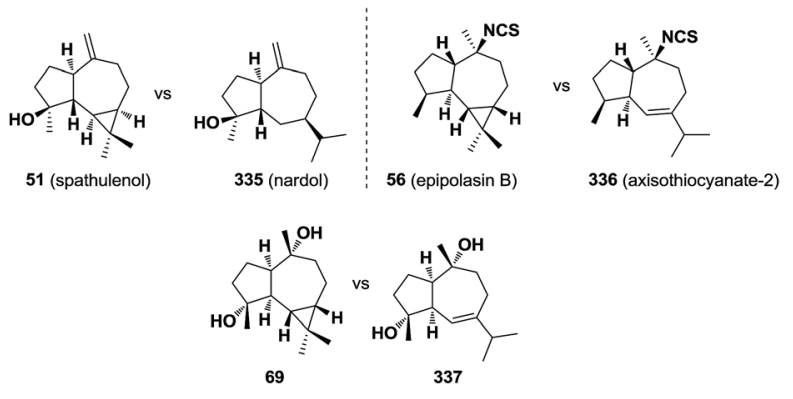

\section{Conclusions}

In summary, this review covered the isolation of sesquiterpenoids containing a gem-dimethylcarbocycle unit and whose biological activities are enhanced. The gem-dimethylcyclopropane ring remains intact in the biogenetic route leading to a large variety of secondary metabolites in many organisms. Nevertheless, many of these compounds have not been assessed in biological assays. This fact suggests that some of these compounds could show interesting unexplored biological activities. For this reason, new assays of inactive or untested compounds should be carried out with the aim of developing structure-activity relationship studies to find either new biologically-active compounds or new biological activities and obtain the common patterns responsible of the activity in these natural products.

\section{Abbreviations}

$\begin{array}{ll}\text { A-2780 } & \text { Human ovarian cancer cell line } \\ \text { A-549 } & \text { Lung adenocarcinoma } \\ \text { A-735 } & \text { Human malignant melanoma } \\ \text { B-16 } & \text { Melanin carcinoma } \\ \text { BC-1 } & \text { Lymphoma cell line } \\ \text { Bel-7402 } & \text { Hepatoma cell line } \\ \text { BGC-823 } & \text { Human gastric adenocarcinoma } \\ \text { CAKI } 1 & \text { Kidney carcinoma } \\ \text { Cinn } & \text { Cinnamoyl } \\ \text { CNS } & \text { Central nervous system } \\ \text { CYP3A4 } & \text { Cytochrome P450 3A4 } \\ \text { Glc } & \text { Glucose } \\ \text { HCT-8 } & \text { Colon cancer cell line } \\ \text { HeLa } & \text { Human cervical epitheloid } \\ \text { HIV-Rtase } & \text { Human immunodeficiency virus reverse } \\ & \text { transcriptase } \\ \text { HT-29 } & \text { Colon adenocarcinoma } \\ \text { Huh-7 } & \text { Cancer cell line } \\ \text { iVal } & \text { Isovaleroyl } \\ \text { Jurkat } & \text { Cancer cell line }\end{array}$




$\begin{array}{ll}\text { KB } & \text { Tumor cell line } \\ \text { KE-97 } & \text { Cancer cell line } \\ \text { MCF-7 } & \text { Breast cancer cell line } \\ \text { MDA-MB- } & \text { Breast adenocarcinoma } \\ 231 & \\ \text { MTT } & \text { 3-(4,5-Dimethylthiazol-2-yl)-2,5- } \\ & \text { diphenyltetrazolium bromide } \\ \text { NCI-H187 } & \text { Lung cell line } \\ \text { SK-Hep1 } & \text { Liver carcinoma } \\ \text { Tig } & \text { Tiglate } \\ \text { U-2 OS } & \text { Osteosarcoma } \\ \text { WISH } & \text { HeLa derivative }\end{array}$

\section{Acknowledgements}

This research was supported by a grant from the Junta de Andalucía (P07-FQM-02925) and in part from MINECO (AGL2012-39798-C02-01).

\section{References}

1 B. M. Fraga, Nat. Prod. Rep., 2013, 30, 1226-1264.

2 B. M. Fraga, Nat. Prod. Rep., 2012, 29, 1334-1366.

3 B. M. Fraga, Nat. Prod. Rep., 2011, 28, 1580-1610.

4 B. M. Fraga, Nat. Prod. Rep., 2010, 27, 1681-1708.

5 B. M. Fraga, Nat. Prod. Rep., 2009, 26, 1125-1155.

6 B. M. Fraga, Nat. Prod. Rep., 2008, 25, 1180-1209.

7 M. J. Durán-Peña, J. M. Botubol-Ares, I. G. Collado and

R. Hernández-Galán, Nat. Prod. Rep., 2014, 31, 940-952.

8 J. R. Hanson, Nat. Prod. Rep., 2013, 30, 1346-1356.

9 J. R. Hanson, Nat. Prod. Rep., 2012, 29, 890-898.

10 J. R. Hanson, Nat. Prod. Rep., 2011, 28, 1755-1772.

11 J. R. Hanson, Nat. Prod. Rep., 2009, 26, 1156-1171.

12 J. Streith, P. Pesnelle and G. Ourisson, Bull. Soc. Chim. Fr., 1963, 518-522.

13 G. Rücker, Angew. Chem., Int. Ed. Engl., 1973, 12, 793-806.

14 W. Parker, J. S. Roberts and R. Ramage, Q. Rev., Chem. Soc., 1967, 21, 331-363.

15 J. D. Connolly and R. A. Hill, Dictionary of terpenoids, ed. E. Chapman and W. Hall, London, 1991, vol. 1.

16 S. Kanokmedhakul, R. Lekphrom, K. Kanokmedhakul, C. Hahnvajanawong, S. Bua-art, W. Saksirirat, S. Prabpai and P. Kongsaeree, Tetrahedron, 2012, 68, 8261-8266.

17 C. Intaraudom, N. Boonyuen, S. Supothina, P. Tobwor, S. Prabpai, P. Kongsaeree and P. Pittayakhajonwut, Phytochem. Lett., 2013, 6, 345-349.

18 M.-A. Tanitsu, Y. Takaya, M. Akasaka, M. Niwa and Y. Oshima, Phytochemistry, 2002, 59, 845-849.

19 M. Clericuzio, C. Cassino, F. Corana and G. Vidari, Phytochemistry, 2012, 84, 154-159.

20 E. Zubia, M. J. Ortega and J. L. Carballo, J. Nat. Prod., 2008, 71, 2004-2010.

21 H. Itokawa, K. Masuyama, H. Morita and K. Takeya, Chem. Pharm. Bull., 1993, 41, 1183-1184.

22 M. L. Liu, Y. H. Duan, Y. L. Hou, H. Gao, Y. Dai and X. S. Yao, Org. Lett., 2013, 15, 1000-1003.
23 A. Bagchi, Y. Oshima and H. Hikino, Phytochemistry, 1988, 27, 2877-2879.

24 Y. Kiso, M. Tohkin and H. Hikino, J. Nat. Prod., 1983, 46, 841-847.

25 H. Hirota, Y. Tomono and N. Fusetani, Tetrahedron, 1996, 52, 2359-2368.

26 T. D. Hubert and D. F. Wiemer, Phytochemistry, 1985, 24, 1197-1198.

27 A. Messer, K. McCormick, H. Sunjaya, H. Hagedorn, F. Tumbel and J. Meinwald, J. Chem. Ecol., 1990, 16, 3333-3352.

28 A. Ulubelen, G. Topcu, C. Eris, U. Soenmez, M. Kartal, S. Kurucu and C. Bozok-Johansson, Phytochemistry, 1994, 36, 971-974.

29 J. Phongmaykin, T. Kumamoto, T. Ishikawa, R. Suttisri and E. Saifah, Arch. Pharmacal Res., 2008, 31, 21-27.

30 J. M. De Siqueira, C. C. De Oliveira and M. A. D. Boaventura, Fitoterapia, 1997, 68, 89-90.

31 M. Murata, Y. Yamakoshi, S. Homma, K. Aida, K. Hori and Y. Ohashi, Agric. Biol. Chem., 1990, 54, 3221-3226.

32 Y. Yamakoshi, M. Murata, A. Shimizu and S. Homma, Biosci., Biotechnol., Biochem., 1992, 56, 1570-1576.

33 K. Osawa, H. Yasuda, H. Morita, K. Takeya and H. Itokawa, J. Nat. Prod., 1996, 59, 823-827.

34 K. Osawa and H. Yasuda, Jpn. Kokai Tokkyo Koho, JP 08109118 A 19960430, 1996.

35 H. Nagata, Y. Inagaki, Y. Yamamoto, K. Meada, K. Kataoka, K. Osawa and S. Shizukuishi, Oral Microbiol. Immunol., 2006, 21, 159-163.

36 R. J. Capon and J. K. MacLeod, Aust. J. Chem., 1988, 41, 979983.

37 H. Ishiyama, S. Kozawa, K. Aoyama, Y. Mikami, J. Fromont and J. Kobayashi, J. Nat. Prod., 2008, 71, 1301-1303.

38 L.-S. Huang, F. He, H. Huang, X.-Y. Zhang and S.-H. Qi, J. Org. Chem., 2012, 8, 170-176.

39 D. K. Tkhu, V. I. Roshchin, O. N. Malysheva and V. A. Solov'ev, Koksnes Kim., 1987, 1, 103-104.

40 H. J. M. Gijsen, J. B. P. A. Wijnberg, G. A. Stork, A. De Groot, M. A. De Waard and J. G. M. Van Nistelrooy, Tetrahedron, 1992, 48, 2465-2476.

41 J. M. Scher, J.-B. Speakman, J. Zapp and H. Becker, Phytochemistry, 2004, 65, 2583-2588.

42 G. Goldsby and B. A. Burke, Phytochemistry, 1987, 26, 10591063.

43 Z.-H. Sun, C.-Q. Hu and J.-Y. Wang, Chin. J. Chem., 2008, 26, 831-834.

44 J. Pika and D. J. Faulkner, Tetrahedron, 1994, 50, 30653070.

45 J. M. Jacyno, M. Montemurro, A. D. Bates and H. Cutler, J. Agric. Food Chem., 1991, 39, 1166-1168.

46 C. Gaspar-Marques, M. F. Simoes and B. Rodriguez, J. Nat. Prod., 2004, 67, 614-621.

47 M. Wessels, G. M. Koenig and A. D. Wright, J. Nat. Prod., 2001, 64, 370-372.

48 M. Nishizawa, M. Emura, Y. Kan, H. Yamada, K. Ogawa and N. Hamanaka, Tetrahedron Lett., 1992, 33, 29832986. 
49 M. Takasaki, T. Konoshima, M. Kozuka, M. Haruna, K. Ito, W. D. Crow and D. M. Paton, Chem. Pharm. Bull., 1994, 42, 2113-2116.

50 N. De Tommasi, C. Pizza, C. Conti, N. Osi and M. L. Stein, J. Nat. Prod., 1990, 53, 830-835.

51 M. F. C. Matos, L. I. S. P. Leite, D. Brustolim, J. M. Siqueira, C. A. Carollo, A. R. Hellmann, N. F. G. Pereira and D. B. Silva, Fitoterapia, 2006, 77, 227-229.

52 S.-P. Yang, X.-W. Zhang, J. Ai, L. Gan, J. Xu, Y. Wang, Z. Su, L. Wang, J. Ding, M. Geng and J. Yue, J. Med. Chem., 2012, 55, 8183-8187.

53 Q. Wang, C. Wang, Y. Zuo, Z. Wang, B. Yang and H. Kuang, Molecules, 2012, 17, 15013-15021.

54 H. Tada and F. Yasuda, Chem. Pharm. Bull., 1985, 33, 19411945.

55 M. Shao, Y. Wang, Z. Liu, D.-M. Zhang, H.-H. Cao, R.-W. Jiang, C.-L. Fan, X.-Q. Zhang, H.-R. Chen, X.-S. Yao and W.-C. Ye, Org. Lett., 2010, 12, 5040-5043.

56 H.-Z. Fu, Y.-M. Luo, C.-J. Li, J.-Z. Yang and D.-M. Zhang, Org. Lett., 2010, 12, 656-659.

57 Y.-J. Tseng, K.-P. Shen, H.-L. Lin, C.-Y. Huang, C.-F. Dai and J.-H. Sheu, Mar. Drugs, 2012, 10, 1572-1581.

58 J. Xiong, S.-T. Liu, Y. Tang, W.-X. Wang, V.-B. Bui, Y. Zhao, H. Fan, G.-X. Yang and J.-F. Hu, Phytochem. Lett., 2013, 6, 586-589.

59 S.-K. Wang, M.-J. Huang and C.-Y. Duh, J. Nat. Prod., 2006, 69, 1411-1416.

60 E. Roemer and T. Grothe, PCT Int Appl, WO 2008074420 A1 20080626, 2008.

61 M. Murata, Y. Yamakoshi, S. Homma, A. Koshi and Y. Nakamura, Biosci., Biotechnol., Biochem., 1992, 56, 2062-2063.

62 M. L. Bolte, J. Bowers, W. D. Crow, D. M. Raton, A. Sakurai, N. Takahashi, M. Ujlia and S. Yoshida, Agric. Biol. Chem., 1984, 48, 373-376.

63 T. Amano, T. Komiya, M. Hori, M. Goto, M. Kozuka and T. Sawada, J. Chromatogr., 1981, 208, 347-355.

$64 \mathrm{H}$. Weenen, M. H. H. Nkunya, Q. A. Mgani, M. A. Posthumus, R. Waibel and H. Achenbach, J. Org. Chem., 1991, 56, 5865-5867.

65 H.-J. Liu, C.-L. Wu, H. Becker and J. Zapp, Phytochemistry, 2000, 53, 845-849.

66 S. H. von Reuss, C.-L. Wu, H. Muhle and W. Konig, Phytochemistry, 2004, 65, 2277-2291.

67 D. Takaoka, N. Kouyama, H. Tani and A. Matsuo, J. Chem. Res., Synop., 1991, 7, 180-181.

68 Y. Asakawa, N. Tokunaga, M. Toyota, T. Takemoto and C. Suire, J. Hattori Bot. Lab., 1979, 45, 395-407.

69 Y. Asakawa, N. Tokunaga, M. Toyota, T. Takemoto, S. Hattori, M. Mizutani and C. Suire, J. Hattori Bot. Lab., 1979, 46, 67-76.

70 Y. Fukuyama and Y. Asakawa, Phytochemistry, 1991, 30, 4061-4065.

71 M. Ramirez, N. Kamiya, S. Popich, Y. Asakawa and A. Bardon, Chem. Biodiversity, 2010, 7, 1855-1861.

72 T. Hashimoto, H. Tanaka and Y. Asakawa, Chem. Pharm. Bull., 1994, 42, 1542-1544.
73 Y. Asakawa, H. Inoue, M. Toyota and T. Takemoto, Phytochemistry, 1980, 19, 2623-2626.

74 M. Toyota, K. Tanimura and Y. Asakawa, Planta Med., 1998, 64, 462-464.

75 Y. Asakawa, Rev. Latinoam. Quim., 1984, 14, 109-114.

76 Y. Asakawa, M. Toyota, T. Takemoto, I. Kubo and K. Nakanishi, Phytochemistry, 1980, 19, 2147-2154.

77 E. W. Jones and F. Rose, J. Bryolog., 1975, 8, 417-422.

78 Y. Asakawa, M. Toyota and T. Takemoto, Tetrahedron Lett., 1978, 18, 1553-1556.

79 A. Matsuo, K. Atsumi, M. Nakayama and S. Hayashi, J. Chem. Soc., Perkin Trans. 1, 1981, 11, 2816-2824.

80 Y.-C. Zhu, G. Wang and J.-K. Liu, J. Asian Nat. Prod. Res., 2010, 12, 464-469.

81 H. Nozaki, J. Chem. Soc., Perkin Trans. 2, 1979, 514-518.

82 N. H. Andersen, P. Bissonette, C. B. Liu, B. Shunk, Y. Ohta, C.-L. W. Tseng, A. Moore and S. Huneck, Phytochemistry, 1977, 16, 1731-1751.

83 N. H. Andersen, Y. Ohta, A. Moore and C.-L. W. Tseng, Tetrahedron, 1978, 34, 41-46.

84 A. Eyles, N. W. Davies and C. Mohammed, J. Chem. Ecol., 2003, 29, 881-898.

85 B. M. Eschler, D. M. Pass, R. Willis and W. Foley, Biochem. Syst. Ecol., 2000, 28, 813-824.

86 S. B. Bharate and I. P. Singh, Bioorg. Med. Chem. Lett., 2011, 21, 4310-4315.

87 M. Takasaki, T. Konoshima, T. Shingu, H. Tokuda, H. Nishino, A. Iwashima and M. Kozuka, Chem. Pharm. Bull., 1990, 38, 1444-1446.

88 M. Takasaki, T. Konoshima, M. Kozuka and H. Tokuda, Biol. Pharm. Bull., 1995, 18, 435-438.

89 G. C. Zheng, A. Ichikawa, M. O. Ishitsuka, T. Kusumi, H. Yamamoto and H. Kakisawa, J. Org. Chem., 1990, 55, 3677-3679.

90 M. Shao, Y. Wang, Y.-Q. Jian, X. J. Huang, D. M. Zhang, Q. F. Tang, R. W. Jiang, X. G. Sun, Z. P. Lv, X. Q. Zhang and W. C. Ye, Org. Lett., 2012, 14, 5262-5265.

91 T. Sawada, M. Kozuka, T. Komiya, T. Amano and M. Goto, Chem. Pharm. Bull., 1980, 28, 2546-2548.

92 M. Kozuka, T. Sawada, E. Mizuta, F. Kasahara, T. Amano, T. Komiya and M. Goto, Chem. Pharm. Bull., 1982, 30, 1964-1973.

93 A. Matsuo, N. Kubota, S. Uto, M. Nakayama, S. Hayashi and K. Yamasaki, Chem. Lett., 1979, 1383-1384.

94 T. Kawabata, T. Hasegawa, Y. Nojiri, C. Uchida, T. Tsubata, H. Kato, F. Takano and T. Ohta, Heterocycles, 2011, 83, 631636.

95 P.-C. Wang, X.-H. Ran, R. Chen, H.-R. Luo, Y.-Q. Liu, J. Zhou and Y.-X. Zhao, J. Nat. Prod., 2010, 73, 1563-1567.

96 T. S. Wu, Y. Y. Chan and Y. L. Leu, J. Nat. Prod., 1998, 61, 511-514.

97 G. T. Maatoq and J. J. Hoffmann, Phytochemistry, 1996, 43, 67-69.

98 E. Rodriguez, G. W. Reynolds and J. A. Thompson, Science, 1981, 211, 1444-1445.

99 X. G. Liu, P. Y. Gao, G. S. Wang, S. J. Song, L. Z. Li, X. Li, X. S. Yao and Z. X. Zhang, Fitoterapia, 2012, 83, 599-603. 
100 J. E. Thompson, R. P. Walker, S. J. Wratten and D. J. Faulkner, Tetrahedron, 1982, 38, 1865-1873.

101 S. Simpson, M. J. Garson, J. N. A. Hooper, E. I. Cline and C. K. Angerhofer, Aust. J. Chem., 1997, 50, 1123-1127.

102 D. E. Barnekow, J. H. Cardellina, A. S. Zektzer and G. E. Martin, J. Am. Chem. Soc., 1989, 111, 3511-3517.

103 J. E. Dellar, M. D. Cole, A. I. Gray, S. Gibbons and P. G. Waterman, Phytochemistry, 1994, 36, 957-960.

104 A. Onogi, K. Osawa, H. Yasuda, A. Sakai, H. Moffta and H. Itokawa, Shoyakugaku Zasshi, 1993, 47, 423-425.

105 S. Kozawa, H. Ishiyama, J. Fromont and J. Kobayashi, J. Nat. Prod., 2008, 71, 445-447.

106 A. Matsuo, S. Uto, H. Nozaki, M. Nakayama and S. Hayashi, J. Chem. Soc., Chem. Commun., 1980, 1220-1222.

107 A. Matsuo, H. Nozaki, N. Kubora, S. Uto and M. Nakayama, J. Chem. Soc., Perkin Trans. 1, 1984, 203-214.

108 A. Matsuo, S. Uto, H. Nozaki and M. Nakayama, J. Chem. Soc., Perkin Trans. 1, 1984, 215-221.

109 Y. Guo, J. Xu, Y. Li, T. Yamakuni and Y. Ohizumi, Planta Med., 2006, 72, 373-375.

110 Y. Guo, J. Xu, Y. Li, R. Watanabe, Y. Oshima, T. Yamakuni and Y. Ohizumi, Chem. Pharm. Bull., 2006, 54, 123-125.
111 H. Ito, H. Iwamori, N. Kasajima, M. Kaneda and T. Yoshida, Tetrahedron, 2004, 60, 9971-9976.

112 S. Maki, N. Asaba, S. Kosemura and S. Yamamura, Tetrahedron Lett., 1992, 33, 4169-4172.

113 H. Tada, T. Tozyo and M. Shiro, J. Org. Chem., 1988, 53, 3366-3368.

114 S. D. Sastry, M. L. Maheshwari and S. C. Bhattacharyya, Tetrahedron Lett., 1966, 10, 1035-1042.

115 M. Silva, A. Wiesenfeld, P. G. Sammes and T. W. Tyler, Phytochemistry, 1977, 16, 379-385.

116 H. Y. He, J. Salva, R. F. Catalos and D. J. Faulkner, J. Org. Chem., 1992, 57, 3191-3194.

117 P. Jumaryatno, B. L. Stapleton, J. N. A. Hooper, D. J. Brecknell, J. T. Blanchfield and M. J. A. Garson, J. Nat. Prod., 2007, 70, 1725-1730.

118 C. Zhang, A. Zhou and M. Zhang, Zhongguo Zhongyao Zazhi, 2009, 34, 994-998.

119 T. Shen, G.-H. Li, Q.-Q. Zhong, S.-Q. Wang, D.-M. Ren, H.-X. Lou and X.-N. Wang, Helv. Chim. Acta, 2014, 97, 881-886. 